\title{
OVERVIEW OF HYDROTHERMAL ACTIVITY ASSOCIATED WITH ACTIVE OROGENESIS AND METAMORPHISM: NANGA PARBAT, PAKISTAN HIMALAYA
}

\author{
C. P. CHAMBERLAIN*, P. O. KOONS**, A. S. MELTZER***, S. K. PARK****, \\ D. CRAW*****, P. ZEITLER***, and M. A. POAGE******
}

\begin{abstract}
The Nanga Parbat Massif is located in northwestern Pakistan and occurs in the interior of the western syntaxis of the Himalaya. Recent studies have shown that the massif exposes an active metamorphic anomaly developed in IndianPlate rocks exhumed from beneath and surrounded by rocks of the Kohistan/Ladakh island-arc. Geochemical and geophysical data from Nanga Parbat show that an active hydrothermal system exists within the massif. In the upper 5 to 6 kilometers of the crust, above a shallow brittle/ductile transition constrained by microseismic data, there is a shallow hydrothermal system with meteoric fluids channelized along active fault zones. In contrast, below the brittle/ductile transition fluids are metamorphic in origin and restricted to unconnected packets along grain boundaries.

The shallow system is stratified with water-rich fluid inclusions near the surface grading to vapor-rich inclusions at the brittle/ductile transition, as evidenced from fluid inclusion studies. These fluids are meteoric in origin and enter the massif along shear and fracture zones and exit the massif along the bordering fault zones. Evidence for these channelized meteoric fluids comes from stable isotopic values of minerals and rocks collected from fault zones that show that these rocks have interacted with meteoric fluids, as well as magnetotelluric (MT) data that show that the fault zones are electrically conductive and embedded in very resistive rocks.

The deeper portions of the hydrothermal system consist of unconnected metamorphic fluids. Stable isotopic and fluid inclusion data show that fluids were present during the recent metamorphism but the rocks did not extensively interact with these fluids. Existence of an unconnected fluid system is supported by the MT studies showing that below the brittle/ductile transition the rocks are relatively resistive (values ranging from 1000-10,000 ohm-m), ruling out an interconnected fluid network. Seismic and MT data also show no evidence of a large magma body at depth.

We suggest that the type of hydrothermal system observed at Nanga Parbat can be an important feature of late-stage orogenic evolution, especially near the tectonically complex edges of orogens. The tectonism in these areas exposes deep, relatively dry rocks that have previously lost their volatile content during the earliest stages of tectonic thickening and metamorphism. These relatively dry rocks are rapidly uplifted and exposed within the massifs where they interact with surface waters at high temperatures and shallow depths.
\end{abstract}

\section{INTRODUCTION}

Numerous studies have shown that fluids play a key role in crustal processes. Fluids influence the rheological response of rocks (Hubbert and Rubey, 1959), redistribute mass (Ague, 1994), and transfer thermal energy (Brady, 1989) within the crust. Because of their importance fluids have been the focus of many geophysical and geochemical studies. However, it is often difficult to integrate these two data sets. In studies of older orogens, magnetotelluric (MT) and seismic studies provide insight

* Department of Geological and Environmental Sciences, Stanford University, Stanford, California 94305-2115

** Department of Geological Sciences, University of Maine, Orono, Maine 04469-5790 18015

*** Department of Earth and Environmental Sciences, Lehigh University, Bethlehem, Pennsylvania,

**** Institute of Geophysics and Planetary Physics, University of California, Riverside, California 92521

****** Geology Department, University of Otago, P.O. Box 56, Dunedin, New Zealand

******* Department of Earth Sciences, Dartmouth College, Hanover, New Hampshire 03755 
regarding the distribution and nature of fluids in the present-day crust. In contrast, petrologic and isotopic studies provide a time-integrated history of the fluids that were present while the crust was deforming and undergoing metamorphism. Difficulty in dating fluids of varying compositions and origins further complicates matters.

Thus, comprehensive, in situ studies of fluid flow are inherently limited by the fact that most metamorphic terranes are relatively old. Where geophysical and geochemical studies have been carried out in active regional metamorphic terranes, fluids have been shown to be an integral part of the tectonic system. At present these coordinated studies have dealt with both modern compressional (for example, the Southern Alps of New Zealand) and extensional settings (the North American Great Basin); and in both of these areas metamorphic and meteoric fluids have been shown to be important components of regional metamorphic hydrothermal systems (Koons and Craw, 1991; Wickham and others, 1993; Jenkin and others, 1994; Upton and others, 1995; Wannamaker and others, 1997, 1998; Davey and others, 1998; Templeton and others, 1998; and Koons and others, 1998).

Although such studies have been critical for understanding the role of fluids during both compression and extension of the crust relatively little is known about the nature and role of fluids during the late stages of orogenic evolution when rapid exhumation can expose hot, dehydrated continental crust. For example, recent work in the Himalaya show that rapid exhumation of deep, hot rocks occurs at the edges of the Indian plate well after initial collision with the Asian plate (Zeitler and others, 2001a, 2001b). The leading edges of the Indian Plate form two major syntaxes: the Namche Barwa massif on the east and the Nanga Parbat massif on the west. In both of these massifs deformation, metamorphism, and magmatism is modern, presumably as a result of strain focusing and exhumation by large rivers that exit the orogen along its edges (Zeitler and others, 2001a, 2001b).

Over the past decade there have been numerous petrologic, isotopic, and geophysical studies of the Nanga Parbat massif to determine the role and nature of fluids when rapid exhumation exposes dehydrated continental crust. The Nanga Parbat massif provides an ideal study area because orogenic processes are ongoing. Thus, by studying an active system it should be possible to extrapolate the results presented herein to older orogenic belts where rapid exhumation must have occurred at some point during its orogenic cycle. In this paper, we synthesize observations from our earlier seismic (Meltzer and others, 2001), magnetotelluric (Park and Mackie, 1997, 2000), and geochemical studies (Chamberlain and others, 1995; Craw and others, 1997; Blum and others, 1998; Gazis and others, 1998; Poage and others, 2000) that allow us to characterize the physical and chemical flow systems at Nanga Parbat. Herein, we present an overview of this work. These integrated data sets, taken together, suggest that below the brittle/ductile transition, fluids are dominantly metamorphic and occur in discrete, unconnected packets. In contrast, above the brittle/ductile transition the fluids are dominantly meteoric and are interconnected. Interaction of this dual hydrothermal system occurs at the brittle/ductile transition, where metamorphic fluids released along fractures and veins mix with downward percolating meteoric fluids.

\section{GEOLOGIC SETTING}

Along much of the Himalayan chain, metamorphism is relatively old (50-10 Ma) and is associated with suturing of the Indian and Asian subcontinents and later thrusting (Searle, 1996; Harrison and others, 1997). However, recent studies (Burg and others, 1997; Zeitler and others, 2001a, 2001b) indicate that at least locally, the nature and timing of metamorphism within both the eastern and western syntaxes is substantially different. In these regions, granulite-grade metamorphism and anatexis 


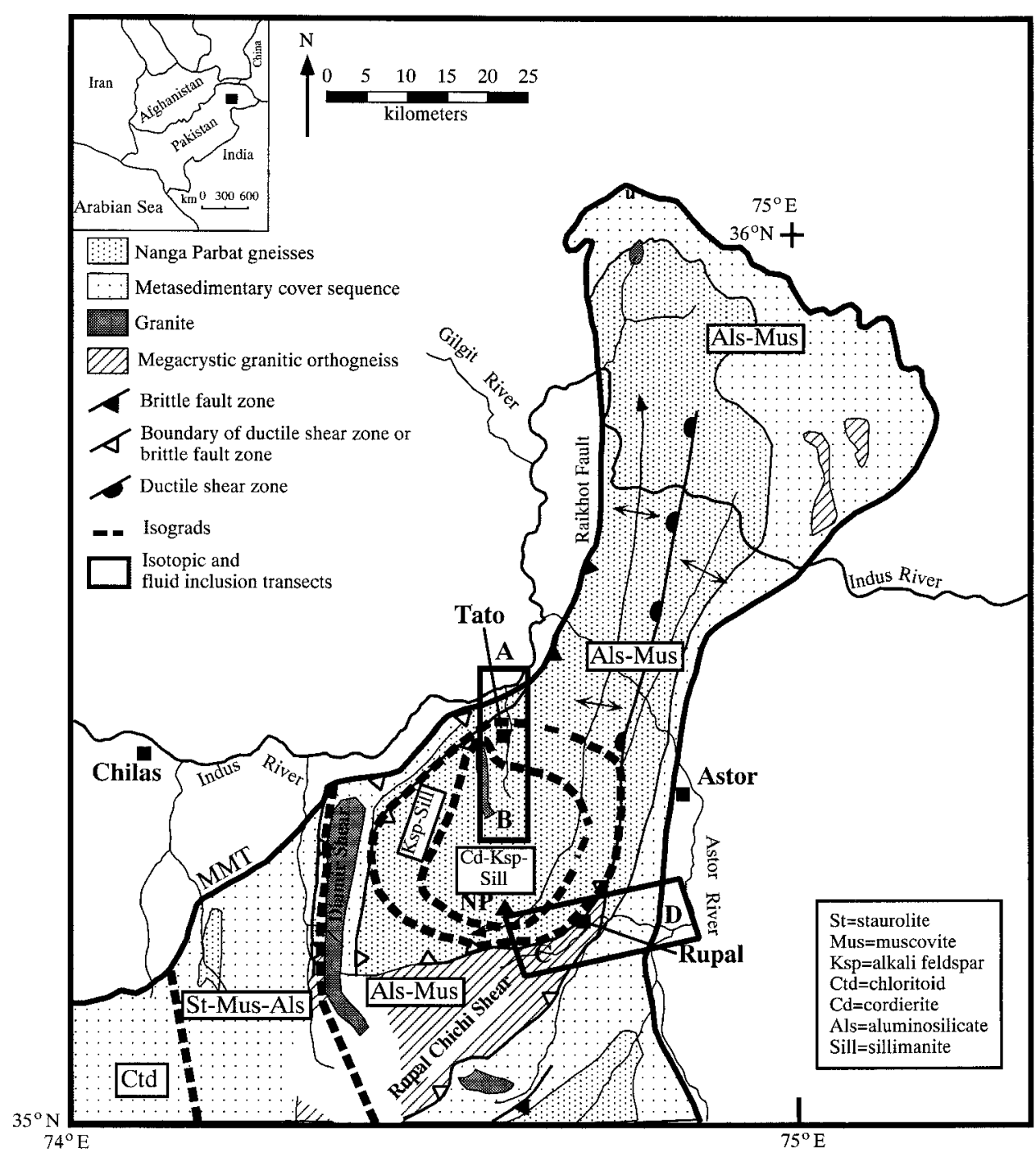

Fig. 1. Map of the Nanga Parbat massif showing major geologic units, metamorphic assemblages, and transects (A-B-C-D) where the isotopic, fluid inclusion, and magnetotelluric data were collected. The trace of the suture between the Kohistan arc and Indian Plate, the Main Mantle Thrust (MMT) is shown as the bold solid line.

are extremely young (1-10 Ma) and are associated with a recent period of extraordinarily high uplift and exhumation.

Within the western syntaxis at the western edge of the Himalaya, the Nanga Parbat-Haramosh Massif (hereafter referred to as NPHM) is a north-south trending body of Indian crust (fig. 1). The massif consists of a core of granulite-grade pelitic gneisses belonging to the Lesser Himalayan sequence (Whittington and others, 2000) and cover rocks belong to the Higher Himalayan Crystalline Series. These Indian crust rocks are in fault contact with Kohistan-Ladakh island arc rocks, which consist of late Cretaceous to Eocene volcanics, amphibolites, and mafic granulites (Tahirkheli and others, 1979). Deformation within the massif began in the Eocene when these 
island-arc rocks were thrust over the Indian plate along the Main Mantle Thrust (Tahirkheli and others, 1979). However, the massif itself was formed in the last $10 \mathrm{Ma}$ as Indian crust was rapidly exhumed along younger faults that crosscut the Main Mantle Thrust (Zeitler, 1985; Butler and Prior, 1988; Zeitler and others, 1989, 1993; Whittington, 1996, ms, 1997; Schneider and others, 1999a). The recent tectonism and rapid exhumation is limited to the core of the massif and is surrounded by Himalayanage metamorphism and deformation in the cover sequence and surrounding Kohistan rocks (Schneider and others, 1999a, 1999b).

The rapid uplift results in young cooling ages (Schneider and others, 1999a) and a shallow, upwardly bowed brittle to ductile transition as evidenced by an abrupt cutoff in seismicity with depth in the core of the massif (Meltzer and others, 2001). Petrologic features form a "bulls eye" pattern such that young $(<10 \mathrm{Ma})$ granulite-grade metamorphic rocks and granites (Zeitler and Chamberlain, 1991; Smith and others, 1992; Whittington and others, 1998; Poage and others, 2000); as well as hydrothermal activity (Chamberlain and others, 1995) are centered on the highest topography (Nanga Parbat) in the area of most rapid uplift. Within the core of the massif the rocks followed nearly isothermal decompression P-T paths and give exhumation rates as high as $\sim 5 \mathrm{~mm} / \mathrm{yr}$ (Zeitler and others, 1993; Poage and others, 2000). In contrast the Himalayan-age metamorphic rocks adjacent to the massif followed clock-wise P-T paths (relative to pressure on the y-axis and temperature on the x-axis) (Chamberlain and others, 1991; Poage and others, 2000). The rapid uplift also resulted in the formation and exposure of migmatites that formed from partial melting of the enclosing gneisses (Gazis and others, 1998; Whittington and others, 1999) and granite dikes and bodies (Zeitler and Chamberlain, 1991).

Petrologic and geochemical analysis show that different generations of igneous rocks formed under both fluid-present and fluid-absent conditions. Based on $\mathrm{Rb} / \mathrm{Sr}$ and $\mathrm{Ba}$ concentrations it has been suggested (Whittington and others, 1999) that the granite bodies and dikes that crosscut the modern foliation were formed under fluid-absent conditions. These granites formed during anatexis at temperatures of $\sim 720{ }^{\circ} \mathrm{C}$ at depths of 20 to 25 kilometers (Whittington and others, 1999), presumably as a result of decompression melting (Zeitler and Chamberlain, 1991). In contrast, migmatites within shear zones located in the high-grade core of the massif formed under fluid-present conditions (Whittington and others, 1998, 1999). The source of this fluid is unknown. However, thermobarometeric constraints suggest that the channelized fluid migration occurred at depths less than 15 kilometers and at temperatures of $\sim 630^{\circ} \mathrm{C}$ (Whittington and others, 1999).

Based on a coupled thermal and mechanical model, it has been suggested (Zeitler and others, 2001a, 2001b; Koons and others, 2002) that young metamorphism, ongoing deformation and recent rapid exhumation of the NPHM is the result of strain focusing induced by erosion. According to these authors, the efficient removal of crust by the Indus River at Nanga Parbat diverts crustal flow into and out of the Nanga Parbat Massif. As the Indus cuts through the massif and turns southward exiting the Himalaya it creates a rheological weak spot in the orogen. The removal of crustal mass by the Indus River concentrates exhumation at the NPHM which in turn results in thermal thinning of the brittle crust and a consequent reduction in the integrated crustal strength in this region. Thus, crustal mass is focused into this rheological weak area and results in high topography, uplifted isotherms, and rapid uplift and exhumation. The concentration of strain produces the domal metamorphic pattern that we observe within the massif.

\section{METHODS}

To augment previous stable-isotope studies of hot-spring waters, gneisses, granites, and quartz veins within the massif (Chamberlain and others, 1995; Gazis and others, 
1998; Poage and others, 2000); we collected additional carbon and oxygen isotopic data for calcite from calc-silicate rocks and oxygen isotopes of quartz veins. We collected samples along a transect that extends from the contact of the Kohistan rocks with the cover sequence at the Raikhot Fault (at the Indus River) through the granulite-grade metamorphic core exposed south of Tato to the Rupal area and up to the Astor River where Kohistan rocks are exposed on the east the of the massif (transect A-B-C-D on fig. 1). As such, the transect crosscuts the young granulite-grade rocks found in the core of the massif and extends into the Himalayan-age rocks exposed in the cover sequence.

Calcite samples were collected from 0.5 to 1 meter beds of calc-silicate rocks that occur within the gneisses and schists of the cover sequence and core rocks of Nanga Parbat. The calc-silicates within the NPPM range in composition from marbles (essentially pure calcite) to wollastonite-anorthite bearing calc-silicates and were documented by Misch (1964). In addition, for comparison we collected calc-silicate rocks from equivalent rocks of lower metamorphic grade exposed several hundred kilometers south of Nanga Parbat in the Naran area. Like Nanga Parbat, in the Naran area both Lesser and High Himalayan rocks are exposed (Smith and others, 1994). However, the peak metamorphism in the Naran only reached amphibolite-grade. For isotopic analysis the calc-silicate rocks were powdered with a dentist drill and 10-30 milligrams of this sample was reacted with 3 milliliters of anhydrous $\mathrm{H}_{3} \mathrm{PO}_{4}$ following the method of McCrea (1950).

Oxygen isotopes were measured on quartz. To obtain high purity quartz separates we used heavy liquid separation techniques to collect the quartz and feldspar fraction; and feldspar was then removed from this fraction by treatment with hydrofluoric acid. 0.5 to 1.0 milligrams of quartz were analyzed on the $\mathrm{CO}_{2}$ laser system at Dartmouth that is described in Conrad and Chamberlain (1992). For NCSU quartz we find an accuracy and precision of $11.7 \pm 0.2$ permil and $5.3 \pm 0.1$ permil. All isotope values were collected on either a Finnigan delta E or 252 located at Dartmouth.

\section{GEOCHEMICAL STUDIES}

\section{Isotopic Studies}

Here we summarize the previous isotopic studies of the Nanga Parbat massif. The pertinent isotopic data is summarized in figures 2,3 and 4 .

The most direct evidence for an active hydrothermal system at Nanga Parbat are the abundant hot springs that occur along faults and shear zones throughout the massif (fig. 1). Hydrogen and oxygen isotopic studies of these hot springs show that the waters have $\delta \mathrm{D}$ and $\delta^{18} \mathrm{O}$ values typical of meteoric water derived from high altitude snow melt (Chamberlain and others, 1995), and show no oxygen or hydrogen isotopic signature from the wall rocks. In contrast, $\mathrm{Sr}$ isotope values and $\mathrm{Ca} / \mathrm{Sr}$ ratios of spring waters show that the hot spring fluids carry Sr derived from silicate rocks (Gazis and others, 1998). This result is not surprising given that the $\mathrm{Sr}$ concentrations in the rocks are 1000 times greater than in the springs (Gazis and others, 1998). Thus, the rocks will buffer the Sr isotopic values of the fluid.

Two lines of isotopic evidence from rock samples suggest that these meteoric fluids interacted with granites and gneisses along shear zones and faults. First, both the $\delta \mathrm{D}$ and $\delta^{18} \mathrm{O}$ values of gneisses from shear and fault zones are lower than values from unfaulted rocks (fig. 2). $\delta^{18} \mathrm{O}$ values of gneisses range from 11.0 to 5.8 permil with a mean value of $8.8 \pm 1.5$ permil, which is 2.3 permil lower than gneisses outside of fault zones. In addition, the $\delta \mathrm{D}$ values of biotites from gneisses in the fault zones are significantly lower $-115 \pm 20.5$ permil than values $-95 \pm 12.2$ permil from unfaulted gneisses (Chamberlain and others, 1995). Second, several of the relatively low $\delta^{18} \mathrm{O}$ granites in the massif show extensive interaction with meteoric fluids. To evaluate 


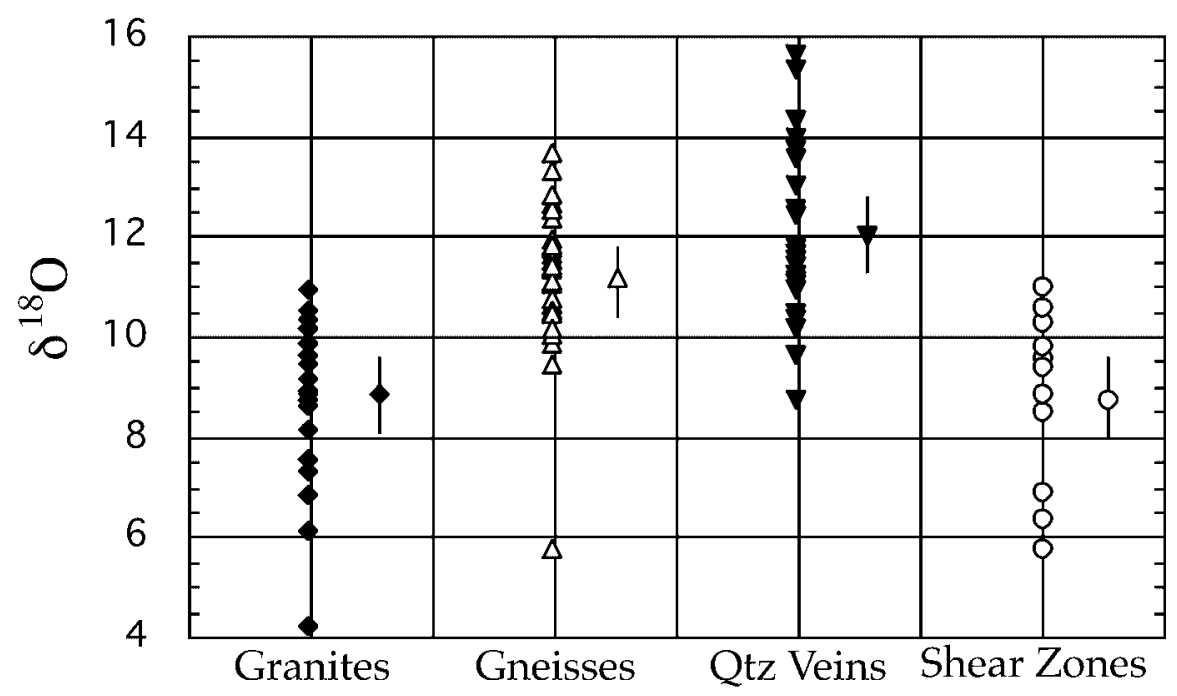

Fig. 2. $\delta^{18} \mathrm{O}$ whole-rock values for rocks and quartz veins from Nanga Parbat. Shown are $\delta^{18} \mathrm{O}$ of granites, gneisses, quartz veins and gneisses from within shear zones. Also shown are the $\delta^{18} \mathrm{O}$ mean and 1 s.d. values for these rocks and veins.

whether the relatively low- $\delta{ }^{18} \mathrm{O}$ granites resulted from interaction of meteoric fluids Chamberlain and others (1995) examined $\delta^{18} \mathrm{O}$ values of potassium feldspar and quartz separates from granites and gneisses from Nanga Parbat. The relatively high$\delta^{18} \mathrm{O}$ granites (from 8 to 12 permil) showed little interaction with meteoric fluids and have $\delta^{18} \mathrm{O}$ potassium feldspar and biotite values consistent with equilibration at magmatic temperatures. In contrast, some, but not all, of the low $\delta^{18} \mathrm{O}$ granites (4.2 to 8 permil) have $\Delta_{\text {qtz-kspar }}$ values that suggest post crystallization exchange with meteoric fluids (Chamberlain and others, 1995). These altered low $\delta^{18} \mathrm{O}$ granites are found in the core of the massif near shear and fault zones. These isotopic data led Chamberlain and others (1995) to conclude that meteoric fluids at high water/rock ratios and at high temperatures have interacted with rocks along fault and shear zones in the massif.

In contrast, isotopic data suggest that unfaulted metamorphic rocks experienced little water/rock interaction (fig. 2; see also Chamberlain and others, 1995). There is a wide range of $\delta^{18} \mathrm{O}$ values for both gneisses and interbedded calc-silicates at Nanga Parbat, which suggests lack of pervasive, isotopically-reactive fluid flow. Although many of the gneisses have $\delta^{18} \mathrm{O}$ values clustering around 11.2 permil, there are a number of gneisses that have $\delta^{18} \mathrm{O}$ values significantly lower and higher, ranging from 5.7 to 13.6 permil (fig. 2). Oxygen isotopic studies of biotite, potassium feldspar, and quartz separates from these gneisses show that the anonymously low values are not the result of high temperature interaction with meteoric fluids (Chamberlain and others, 1995) but instead represent pre-metamorphic isotopic heterogeneities.

Similarly, our new $\delta^{13} \mathrm{C}$ and $\delta^{18} \mathrm{O}$ values of calcite from calc-silicate beds (fig. 3) also show a wide range of values from -10.8 to 6.4 percent in $\delta^{13} \mathrm{C}$ (mean $=-2.8$ permil \pm 3.70$)$ and 0.43 to 27 permil in $\delta^{18} \mathrm{O}$ (mean $=14.7$ permil \pm 5.45$)$. In addition to the wide scatter in isotopic values of Nanga Parbat calc-silicates the $\delta^{13} \mathrm{C}$ and $\delta^{18} \mathrm{O}$ of these rocks are much lower than less metamorphosed garnet-grade equivalent rocks exposed south of the massif in the Naran area (fig. 3). The mean $\delta^{13} \mathrm{C}$ and $\delta^{18} \mathrm{O}$ of lower-grade calc-silicates are 0.72 permil \pm 3.59 and 19.6 permil \pm 3.24 , respectively.The lower isotopic values could be interpreted to be the result of infiltration of fluids 


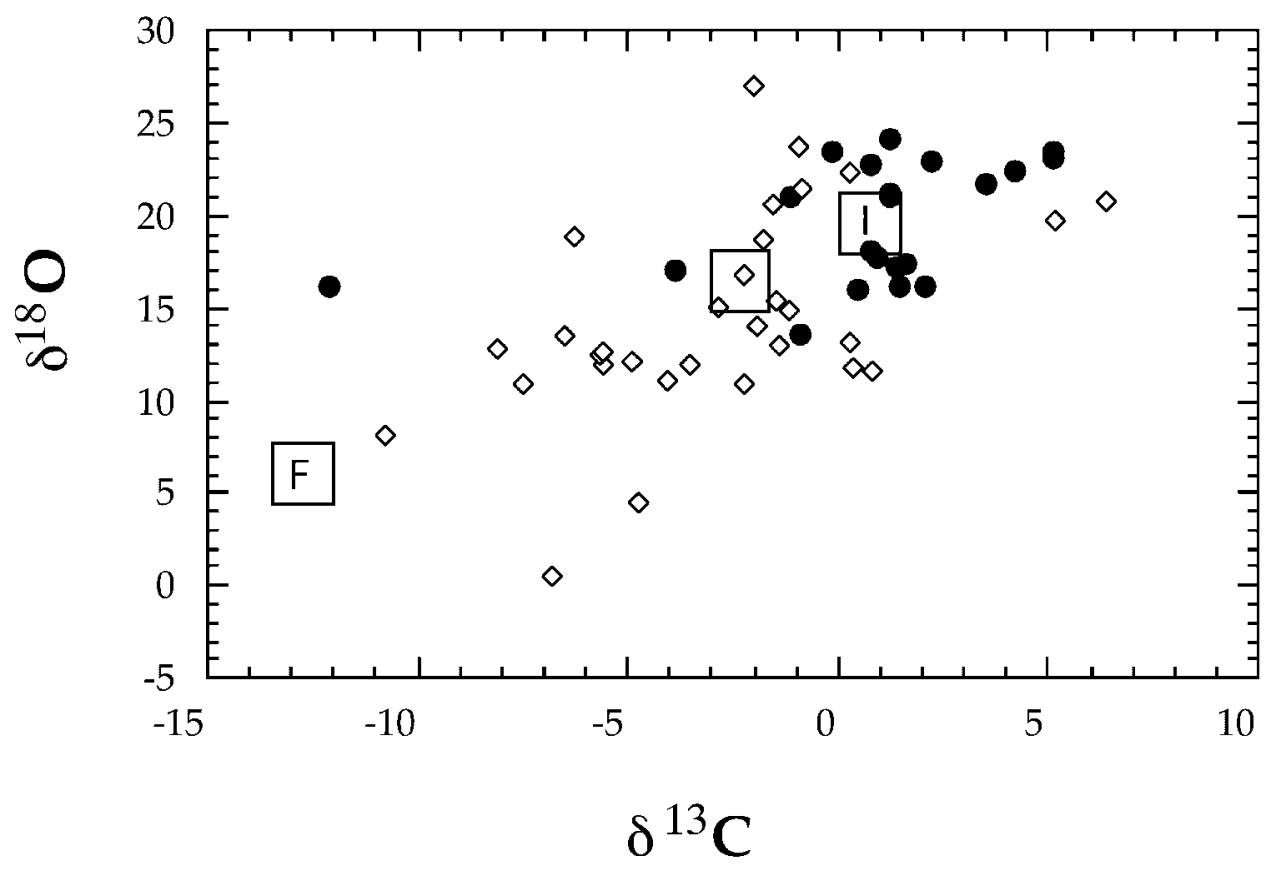

Fig. 3. $\delta^{13} \mathrm{C}$ versus $\delta^{18} \mathrm{O}$ for calcite from calc-silicate rocks from Nanga Parbat (open diamonds) and lower-grade equivalent rocks exposed in the nearby Naran area of Pakistan (dots). The box labeled I shows the mean isotopic values of the low-grade rocks. The calculated isotopic values for Rayleigh fraction during devolatilization are shown for the calc-silicate limit (open box) and for the most extreme devolatilization (that is; Rayleigh model at completion, box labeled F).

derived from the isotopically lighter gneisses or the reduction of isotopic values as a result of Rayleigh fractionation of isotopes during devolatilization reactions.

We suggest that both of these processes occurred during metamorphism. The calc-silicate rocks at Nanga Parbat are at granulite grade and contain ubiquitous wollastonite (Misch, 1964) which is lacking in the lower amphibolite grade calcsilicates in the Naran region. Based on Rayleigh fractionation calculations we suggest that devolatilization reactions could produce changes of approximately 2 permil in $\delta^{18} \mathrm{O}$ values of calcite from low- (box I) to high-grade (open box) (fig. 3). This assumes that devolatilization does not exceed the theoretical "calc-silicate limit" based on the stoichiometry of volatilization reactions (see Valley, 1986). However, many of the high-grade calc-silicate rocks contain calcite with more extreme depletions in ${ }^{18} \mathrm{O}$ than plausible from devolatilization reactions alone (points to the left of the open box in fig. $3)$. The most likely explanation for these extreme depletions in ${ }^{18} \mathrm{O}$ is exchange with isotopically lighter fluids derived from the adjacent gneisses. This explanation is consistent with the work of Gazis and others (1998) that showed that a fluid phase carrying Sr exchanged between the gneisses and calc-silcate rocks during metamorphism.

Evidence for this fluid phase are numerous small $(<1 \mathrm{~mm})$ calcite veinlets found within the gneisses at Nanga Parbat (Blum and others, 1998). Strontium isotope analyses of these veins and enclosing wall rock suggest that the fluids that formed the veins were derived from the local calc-silicate rocks (Gazis and others, 1998). In addition, based on diffusion calculations and ${ }^{87} \mathrm{Sr} /{ }^{86} \mathrm{Sr}$ isotopic analyses Gazis and others (1998) were able to show that the veinlets formed at temperatures between $300^{\circ}$ to $600{ }^{\circ} \mathrm{C}$ within the last 5 myr. 

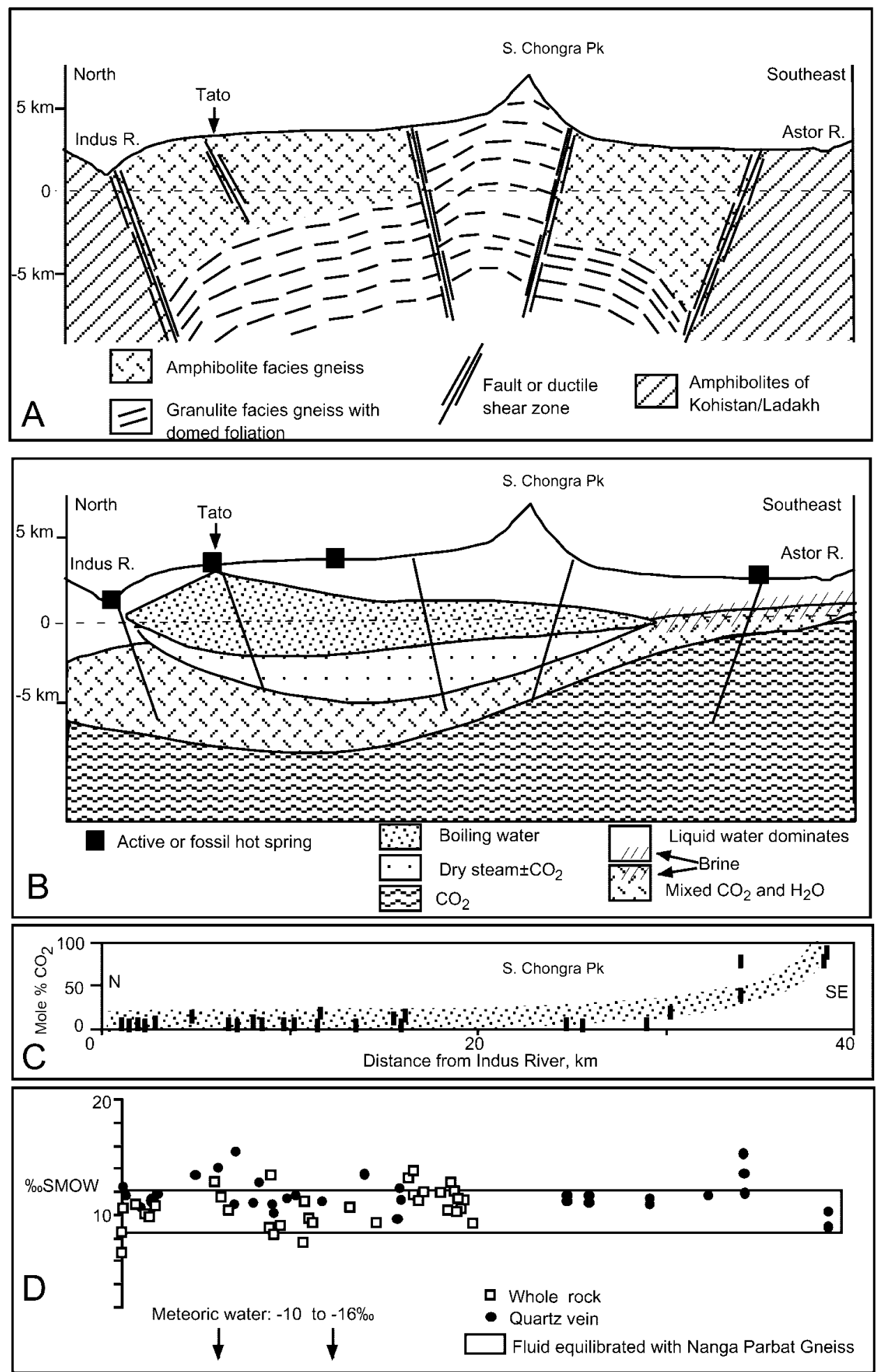

Fig. 4. Composition of fluid inclusions along transect A-B-C-D (fig. 1) at Nanga Parbat (modified from Poage and others, 2000). Shown on this figure are the generalized lithologic and structural cross section across the massif (A); and subsurface fluid inclusion data (B). The depths are inferred from fluid inclusion data. Note also the mole percent $\mathrm{CO}_{2}$ in the fluid inclusions increases dramatically in rocks toward the east edge of the massif $(\mathrm{C})$. Also shown are the $\delta^{18} \mathrm{O}$ values of gneisses (squares) and quartz veins (dots) and the fluid that would be in equilibrium with these gneisses and veins during metamorphism (shaded rectangle). Note that the $\delta^{18} \mathrm{O}$ values of both rocks and veins decrease within shear and fault zones (D). 


\section{Fluid Inclusion Studies}

At Nanga Parbat, it is possible to use fluid inclusions to construct a vertical profile of fluid compositions as well as the evolution of fluids through time for two reasons. First, geochronological studies show that the rapid exhumation stage has been occurring for at least 3 to $5 \mathrm{Ma}$ (Zeitler and others, 2001a, 2001b). Thus, rocks exposed at Nanga Parbat were at the brittle/ductile transition only 1 myr ago. Second geomorphic and cosmogenic isotope studies suggest that uplift and exhumation are in steady state (Burbank and others, 1996). If we assume steady state, at least over the past 3 to $5 \mathrm{Ma}$, we can use fluid inclusions of different vein sets (for example, veins ductilely deformed, veins crosscutting metamorphic foliation, et cetera) to construct a relative time and depth stratigraphy of fluid composition.

Studies of fluid inclusions in the Nanga Parbat Massif show that the nature of fluids varies both with depth and laterally within the massif (Winslow and others, 1994; Craw and others, 1994, 1997; Poage and others, 2000). Fluid inclusions from quartz veins that crosscut young ( $<2 \mathrm{Ma}$ ) metamorphic fabrics (Craw and others, 1994, 1997; Poage and others, 2000) as well as from minerals in the Nanga Parbat gneisses (Winslow and others, 1994) allow for delineation of the fluid regimes shown in figure 4.

Within the massif, the nearest surface fluid inclusions occur as late stage crosscutting fractures within quartz veins. There are two types of inclusions that occur in this zone. First, there are veins that are dominated by liquid water with less than 20 percent vapor bubbles and low salinities $(<2$ weight percent $\mathrm{NaCl}$ equivalent). Homogenization temperatures suggest that these inclusions formed between $240^{\circ}$ and $330^{\circ} \mathrm{C}$ (Poage and others, 2000). Second, there are coexisting liquid- and vapor-rich inclusions that have slightly higher homogenization temperatures (between $340^{\circ}$ and $390^{\circ} \mathrm{C}$ ) and higher salinities (up to 5 weight percent $\mathrm{NaCl}$ equivalent). These inclusions have been interpreted to form as a result of fluid boiling near the critical point in the $\mathrm{H}_{2} \mathrm{O}-\mathrm{CO}_{2}$ system (Craw and others, 1994). The depth at which these two types of fluid inclusions formed is constrained by the fact that some of these inclusions were formed during boiling. Based on this evidence the depth to the boiling zone is inferred to be $\sim 2$ to 6 kilometers below the surface (Craw and others, 1994) but locally must intersect the surface where the boiling hot springs exit the massif along the Raikhot Fault and at Tato (fig. 4).

Beneath this zone are secondary dry steam fluid inclusions within postmetamorphic quartz veins (fig. 4). These unusual inclusions are predominantly vapor-rich, have low salinites ( $\sim 5$ weight percent), and give homogenization temperatures of up to $415^{\circ} \mathrm{C}$ (Craw and others, 1997). In quartz veins where both boiling (mentioned above) and dry steam inclusions occurs, crosscutting relationships show that the dry steam inclusions are older than the liquid water/boiling inclusions. The depth of the dry steam zone is poorly constrained but it must extend beneath the boiling zone and could extend down to the brittle/ductile transition where these veins formed ( $\sim 5 \mathrm{~km}$ below sea level based on the lower limit of seismic activity).

The deepest portion of the system is characterized by fluid inclusions found within metamorphic minerals (not veins) in the massif (Winslow and others, 1994). These fluid inclusions are mixed $\mathrm{H}_{2} \mathrm{O}$ and $\mathrm{CO}_{2}$ compositions with higher salinities (up to 36 weight percent $\mathrm{NaCl}$ equivalents). These inclusions give homogenization temperatures of up to $450^{\circ} \mathrm{C}$, formed at depths of $\sim 5$ kilometers; and are interpreted to be late stage fluids of metamorphic origin.

In general, the fluid inclusions discussed above have $\mathrm{CO}_{2}$ contents and salinities that vary systematically with their inferred depth. Typically, deeper fluids have higher $\mathrm{CO}_{2}$ concentrations and salinities than inclusions formed in the shallow portion of Nanga Parbat. In addition to these depth relationships there are also systematic 
variations laterally within the massif (fig. 4). The boiling and dry steam zones extend from the Indus River to near the summit of Nanga Parbat and, with the exception of two debris samples from the Rupal face, are not found east of Nanga Parbat (Poage and others, 2000). $\mathrm{CO}_{2}$-rich fluid inclusions are dominantly found on the east-edge of the massif, an area that has the slowest exhumation rates and Himalayan-aged metamorphism.

\section{GEOPHYSICAL STUDIES}

\section{Magnetotelluric Studies}

The MT studies reveal very resistive rocks both above and below the brittle/ductile transition, with narrow conductive zones where active faulting and fluid flow can be seen at the surface (Park and Mackie, 1997, 2000). These high resistivities can be explained by low interconnected fluid content in the rocks, an explanation that is consistent with channelized fluid flow above the brittle/ductile transition and isolated, stagnant pockets of metamorphic fluids below it. The surprising result from Park and Mackie (2000) is that the crust to depths of at least 40 kilometers below sea level (bsl) is generally very resistive (minimum average values of $1000 \mathrm{ohm}-\mathrm{m}$ and 10,000 ohm-m preferred) in an active orogen with fluid flow and water-rock interactions (fig. 5). These high resistivities are consistent with laboratory measurements of dry granulites and petrologic models of granulite grade metamorphism which show that free water is taken up by hydration reactions.

The MT method is sensitive primarily to conductors because they channel the natural electrical currents. Silicate minerals are very resistive, so they generally contribute little to the overall conductivity of a rock. In contrast, small fractions of fluids, partial melt, and solid phase conductors such as graphite are responsible for increasing the conductivity of a rock. Two conditions must be met for a rock to be conductive: 1) it must contain a conductive fraction, and 2) that fraction must be interconnected. Given the evidence for a hydrothermal system at Nanga Parbat and the presence of young leucogranites, we will limit our discussion here to the role of aqueous fluids and of silicic partial melt, both of which can act as conductors.

The MT results indicate that fluids are focused along fault zones at Nanga Parbat as both the Raikhot fault zone and the Rupal Chichi shear zone are conductive (fig. 5). In the surrounding rocks, interconnected fluids are largely absent. Park and Mackie (2000) estimated that only $40 \mathrm{ppm}$ of interconnected fluid with a salinity of 3.5 weight percent would be needed to explain the $1000 \mathrm{ohm}-\mathrm{m}$ average resistivity. More fluid could certainly be present, but it could not be interconnected. Park and Mackie (2000) also showed that a few conductive shear zones with cross sectional areas of $2.25 \mathrm{~km}^{2}$ could have been missed in the MT study because of the sparse site spacing. Such a shear zone could be 500 meters wide and 4.5 kilometers long. In any case, the MT models (fig. 5) are consistent with a model of channelized flow along shear zones and little water-rock interaction in the surrounding granulite grade metamorphic rocks.

The MT results are also consistent with relatively little interconnected fluids in the unfaulted portions of Nanga Parbat. Using fluid inclusion data it is possible to constrain the amount of fluid present. As mentioned previously, fluid inclusion analyses show that the shallow hydrothermal system is also chemically stratified. The shallow section $(<2 \mathrm{~km}$ depth) is dominated by low salinity ( $<2$ weight percent) liquid water at temperatures of $240^{\circ}$ to $340^{\circ} \mathrm{C}$. Nesbitt (1993) shows these salinities result in a fluid resistivity of $0.08 \mathrm{ohm}-\mathrm{m}$. Assuming that the fluids reside in fractures (as evidenced by quartz veins) the rock resistivity is given by $\rho_{\text {rock }}=\rho_{\text {fluid }} \mathrm{f}^{-1}$ (where $\mathrm{f}$ is the fraction of interconnected fluid), and, therefore, we need only $80 \mathrm{ppm}$ of fluid to explain the $1000 \mathrm{ohm}-\mathrm{m}$ average resistivity. At deeper levels of 2 to 6 kilometers, the salinity is higher ( 5 weight percent) but the fluid inclusions indicate boiling fluids in 


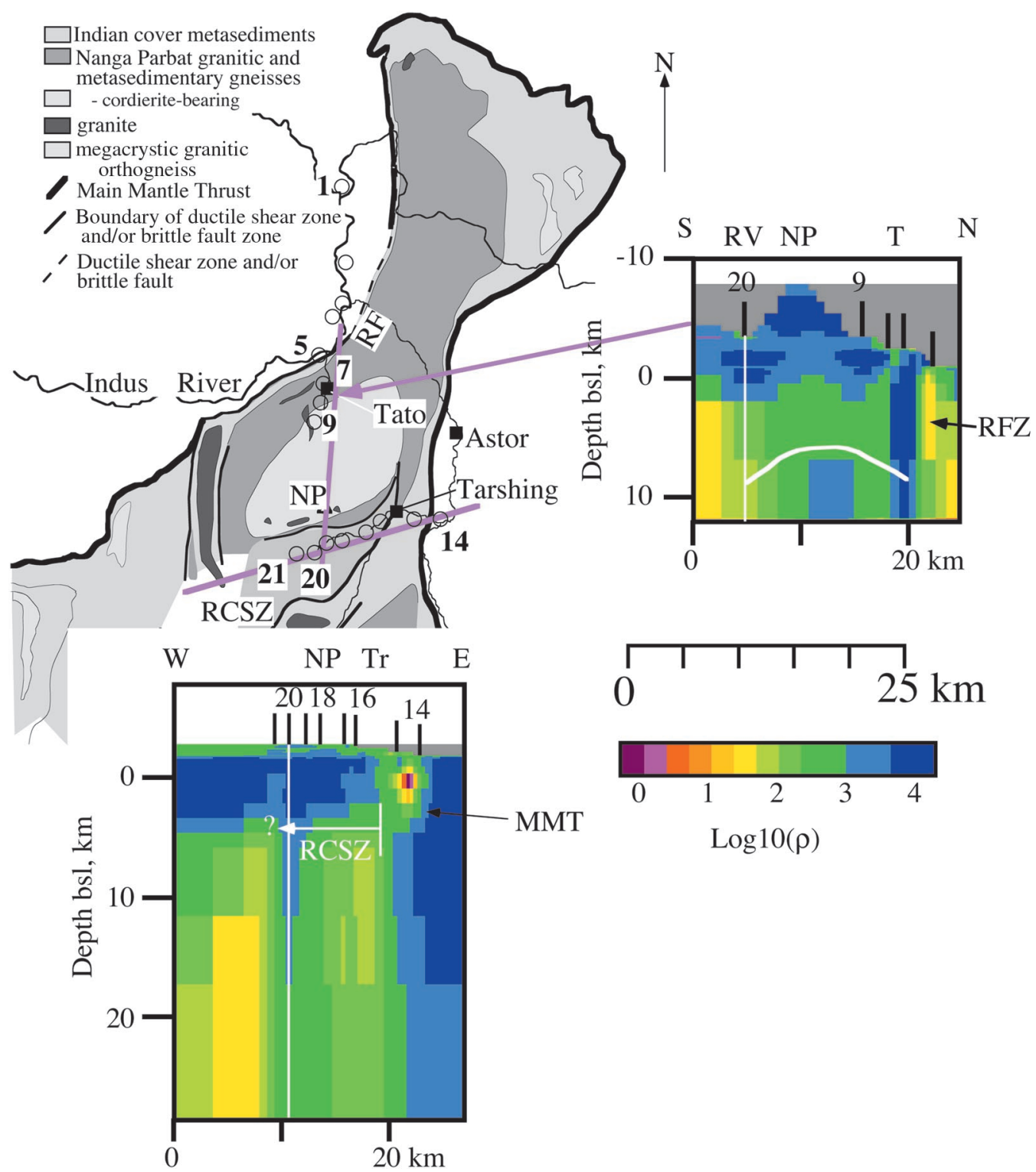

Fig. 5. Summary of results from MT study in Park and Mackie (2000). N-S and E-W resistivity cross sections are shown with pink lines on geologic map adapted from Schneider and others (1999a). White vertical lines on sections show where the two cross. Sections are scaled to 1:1 and depths are referred to below sea level (bsl). White curved line at a depth of 8-10 km on the N-S section marks the lower limit of seismicity and presumably the brittle-ductile transition. Symbols used are: MMT, Main Mantle Thrust; NP, Nanga Parbat; RF, Raikhot fault; RCSZ, Rupal Chichi shear zone; RV, Rupal Valley; T, Tato; and Tr, Tarshing.

an $\mathrm{H}_{2} \mathrm{O}-\mathrm{CO}_{2}$ system at temperatures of $340^{\circ}$ to $390^{\circ} \mathrm{C}$. This boiling would generate a nonconductive gas phase and a more conductive aqueous residual fluid. Calculations of the resistivity of the rock might increase by as much as a factor of two under such conditions, but this is not a significant change for rock resistivity and falls within the range of 1000-10000 ohm-m observed by Park and Mackie (2000). At the deepest 
levels above the brittle/ductile transition, salinities of 5 weight percent are observed in a dry steam system. Again, a vapor-dominated system will have high resistivities because the vapor will be nonconducting.

Rocks below the brittle/ductile transition are still quite resistive (fig. 5), with values ranging from 1000-10000 ohm-m. This result suggests that only small amounts of interconnected fluids are present below the brittle/ductile transition. Some constraints can be placed on the amount of interconnected fluid based on fluid inclusion data. Fluid inclusion studies reported show $\mathrm{H}_{2} \mathrm{O}-\mathrm{CO}_{2}$ fluids with high salinities (35 weight percent) at temperatures exceeding $450^{\circ} \mathrm{C}$ in a few fluid inclusions, but most are dominated by $\mathrm{CO}_{2}$. While the brines will be conductive, the $\mathrm{CO}_{2}$-rich fluids will be resistive. Extrapolation of Nesbitt's (1993) results to a salinity of 35 weight percent yields a solution resistivity of $0.01 \mathrm{ohm}-\mathrm{m}$. Given an average rock resistivity of 1000 ohm-m, only $10 \mathrm{ppm}$ of interconnected fluid need be present in the rock in order to explain its finite resistivity. One possible complication is that the metamorphic fluids are $\mathrm{CO}_{2}$-rich (Poage and others, 2000), and this component is nonconducting. Poage and others (2000) further reports that some of these fluids are immiscible. Duan and others (1995) show that the immiscibility field for $\mathrm{H}_{2} \mathrm{O}-\mathrm{CO}_{2}$ fluids is expanded by the addition of $\mathrm{NaCl}$. This immiscibility would result in the concentration of the $\mathrm{NaCl}$ into a highly saline $\mathrm{H}_{2} \mathrm{O}$ brine filling the interstices between the $\mathrm{CO}_{2}$ fractions. Such a brine would wet the mineral surfaces, preserving an interconnected network. Calculations of this partitioning show that the resistivity of the overall fluid does not increase by more than a factor of two as it enters the immiscibility field. Increasing the amount of interconnected, conducting fluid by more than a factor of two is thus inconsistent with the MT data. The MT data cannot constrain the amount of fluid that is not part of the interconnected fraction, however.

One unresolved question is whether substantial silicic melt could be present beneath the brittle/ductile transition. Wannamaker (1986) shows that the resistivity of a silicic melt is dependent on its water content and can vary from $0.1 \mathrm{ohm}-\mathrm{m}$ for water-saturated melting to $1000 \mathrm{ohm}-\mathrm{m}$ for dry partial melting. Whittington and others (1999) estimate that melting begins at $720^{\circ} \mathrm{C}$ and $8 \mathrm{kbars}$ with 4 weight percent water in the melt. A water content of 4 weight percent for the melt means that a water activity of 0.6 to 0.7 and therefore a resistivity of $0.2 \mathrm{ohm}-\mathrm{m}$ can be expected (Wannamaker, 1986). There is sufficient water in the melt to lower its resistivity substantially. The MT data thus do not permit large melt reservoirs beneath Nanga Parbat, although Park and Mackie (2000) showed that regions with areal conductances (cross sectional area times conductivity) of less than $2.3 \times 10^{5} \mathrm{~S}$ meters could be missed. Reservoirs with cross sectional areas of less than $0.045 \mathrm{~km}^{2}$ (or $212 \mathrm{~m} \times 212 \mathrm{~m}$ ) could therefore be present. Such small melt bodies are consistent with the passage of shear waves and the scattering of seismic waves below the brittle/ductile transition (see below).

\section{Seismic Studies}

Seismic experiments carried out at Nanga Parbat (Meltzer and others, 2001) allow us to place additional constraints on the location of the brittle/ductile transition, the occurrence of magmas, and the distribution of hydrothermal fluids. Local events recorded by the sixty-station array over a several year period were used to determine local fault kinematics. Local, regional, and teleseismic events were inverted for velocity and attenuation structure beneath the massif. The seismic experiment and primary seismic results are documented in Meltzer and others (2001) and briefly summarized in this paper.

Seismicity is distributed along strike beneath the massif and exhibits a sharp drop-off west of the massif and a gentler drop-off east of the main summit ridge crest (fig. 6). The sharp cut-off in seismicity to the west corresponds to the mapped trace of the Raikhot fault where it is coincident with the Indus River. Seismic activity also shows 


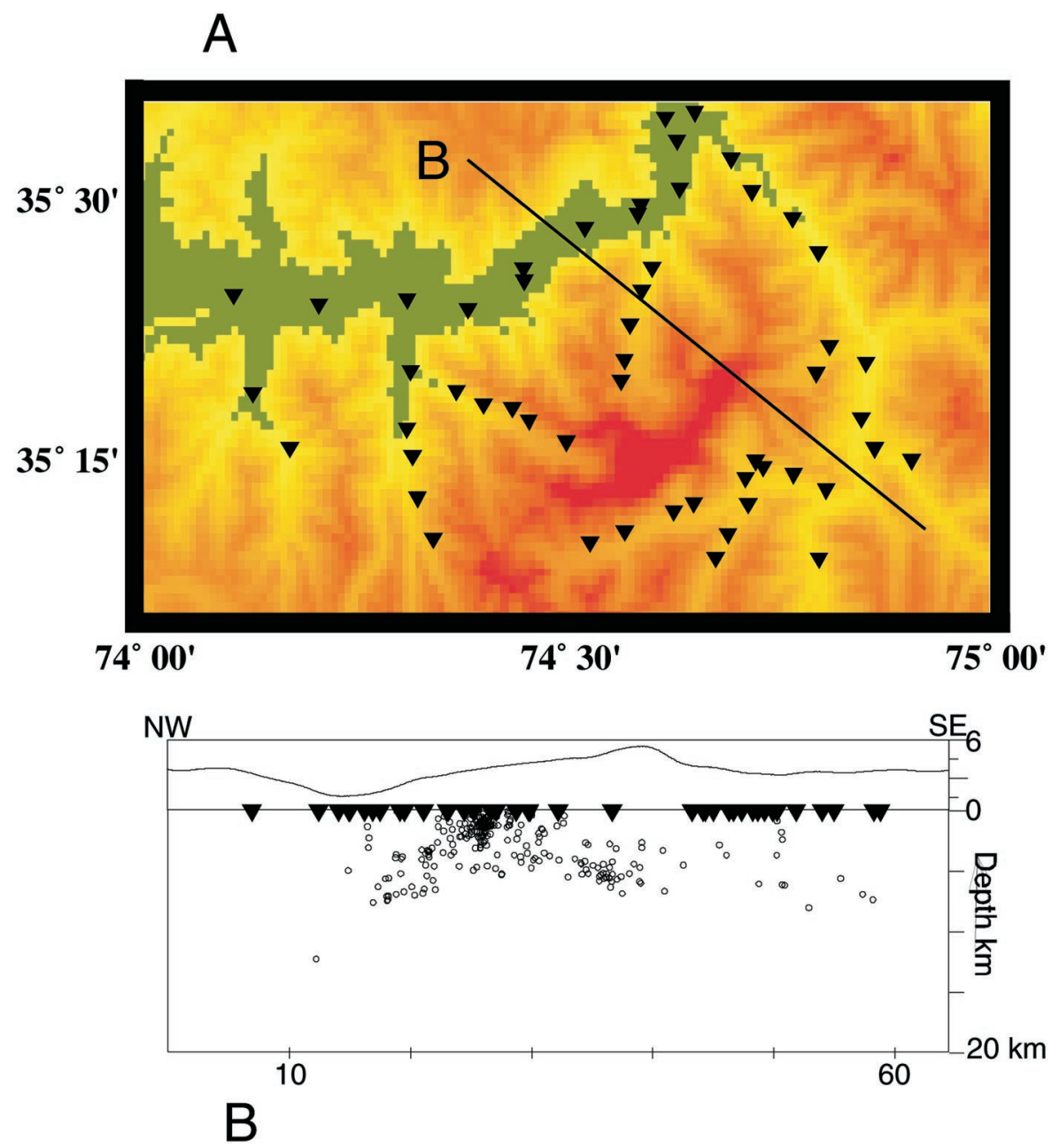

Fig. 6. (A) Regional seismicity of the Nanga Parbat massif. This figure shows station locations (triangles) and local events (circles). Colors show topography with greens low topography and oranges highest topography. (B) Epicenters in B projected to cross-section.

that brittle deformation is largely restricted to depths $\leq 2$ kilometers below sealevel $(\sim 5-6 \mathrm{~km}$ below the average topographic surface) and forms an antiformal pattern underneath the massif. Sixty-five percent of the local events occurred above sea level. Another 27 percent occurred between 0 to 2 kilometers depth below sealevel. The base of seismicity forms a prominent antiformal shape beneath the massif and exhibits considerable structural relief, approximately 3 kilometers in a lateral distance of 12 kilometers (fig. 7). The apex of this antiform occurs at 5 kilometers depth below sea level and is offset approximately 10 kilometers northwest of the topographic ridge crest. The base of seismicity deepens to 8 kilometers below sealevel to the northwest and southeast, mapping a thermal boundary and a transition between brittle and plastic deformation that takes place over a $\sim 3$ kilometer thick zone. There is no seismicity deeper than 8 kilometers depth (below sealevel) beneath the massif. 
There is some evidence from the seismic activity for focusing of fluids along fault zones. While some thrust and strike-slip focal mechanisms were recorded, much of the observed seismicity exhibits extensional mechanisms consistent with extension above the doubly vergent thrust system bounding the massif. However, a cluster of seismicity is associated with the Tato hot springs including a swarm of 26 events in a 24-hour period. Hypocenters locate within \pm 50 meters of each other defining a fault plane that may serve as a pathway for circulation of meteoric water to and from the surface. Whereas we see many seismic events with clean impulsive arrivals and easily identifiable $\mathrm{P}$ and $\mathrm{S}$ phases, others arrivals appear more harmonic, similar to source signatures associated with geothermal systems. These results are consistent with: 1) the MT data that show interconnected fluids are largely absent in the upper crust and are highly channelized along fault and shear zones; 2) the relatively unique hydrothermal system where boiling fluids dominate to $\sim 2$ kilometers depth below sealevel and dry steam system (vapor phase only) dominates below these depths down to the brittle/ductile transition; and 3) the isotopic data that indicate that meteoric fluids are focused along fault and shear zones.

The seismic data allow us to place three additional constraints on the deeper portions of the Nanga Parbat massif. First, there is little evidence for large-scale magma bodies underneath Nanga Parbat. Abundant $\mathrm{S}$ wave arrivals at stations throughout the array rule out the possibility of a substantial magma body beneath Nanga Parbat, a result consistent with the MT results. Using a 3-D joint inversion for hypocenter location, Vp, and Vs shows that the seismic velocity structure beneath Nanga Parbat is anomalously low over lateral distances of 10 to 20 kilometers (Meltzer and others, 2001). Both $\mathrm{P}$ and $\mathrm{S}$ wave low velocity anomalies are observed within the core of the massif and extend to depth through the entire crust and into the upper mantle (Meltzer and others, 2001). Both $\mathrm{P}$ and $\mathrm{S}$ arrivals exhibit similar variations (that is, varying together and in approximately the same proportions). In the presence of melts, $\mathrm{S}$ waves should be reduced more than $\mathrm{P}$ waves resulting in high $\mathrm{Vp} / \mathrm{Vs}$ ratios. It is, therefore, unlikely that large granite bodies produced by fluid infiltration occur at Nanga Parbat, as has been proposed for other regions of the Himalayas (Le Fort and others, 1987).

Second, comparison of RMS amplitude and estimates of seismic attenuation of $\mathrm{P}$ and $\mathrm{S}$ waves indicate that the crust beneath the massif attenuates seismic energy significantly more than the surrounding terrane. Path-averaged attenuation results show $Q$ values for paths that traverse the core of the Nanga Parbat massif are 3 to 4 times lower than that for paths that stop outside the massif. The region of high attenuation appears to extend throughout the entire crust, and possibly to the uppermost mantle. Both $Q_{p}$ and $Q_{s}$ exhibit similar results. Parameterization that allows both vertical and lateral variations shows a sharp boundary of high- $Q^{-1}$ and low- $Q^{-1}$ that lies beneath the core of the Nanga Parbat massif. This high attenuation region coincides with the region of low seismic velocities (which in turn correlates with the region of highest topography, high geothermal gradients, and young high-grade igneous and metamorphic rocks). Inversion results along with comparison of $Q_{s}$ to $Q_{\text {coda }}$ indicate that intrinsic absorption rather than scattering is dominant for the observed $Q^{-1}$ values. Thus $Q^{-1}$ can be presumed to be a reasonable proxy for thermal anomalies beneath Nanga Parbat; and consequently temperature beneath Nanga Parbat could exceed that beneath the surrounding terrane by $\sim 100^{\circ}$ to $200^{\circ} \mathrm{C}$.

Third, seismic results are consistent with small amounts of partial melt and supercritical fluid in the core of the massif. Estimates of thermal gradients from thermobarometry suggest that temperatures at depths of 14 to 20 kilometer depth beneath Nanga Parbat reach $600^{\circ}$ to $800^{\circ} \mathrm{C}$ (Poage and others, 2000). The 5 to 10 
percent reduction ( $\sim 0.4-0.7 \mathrm{~km} / \mathrm{s}$ anomalous low velocities) in seismic velocity and attenuation observed in the core of the massif is consistent with temperatures in this range. At these temperatures, felsic rocks are hot enough to partially melt. Although there is no evidence of a large continuous magma body beneath Nanga Parbat, we see local travel time delays and anomalous waveforms suggesting small scale heterogeneity possibly related to small partial melt zones consistent with the migmatite zone in the core of the massif. Local events display a large variation in waveform coda associated with propagation path (Meltzer and others, 2001). However, tomographic inversions yield slightly low to average $\mathrm{Vp} / \mathrm{Vs}$ ratios within the massif arguing against substantial partial melt fractions. Low $\mathrm{Vp} / \mathrm{Vs}$ ratios may reflect the presence of super-critical fluids in small regions of limited extent.
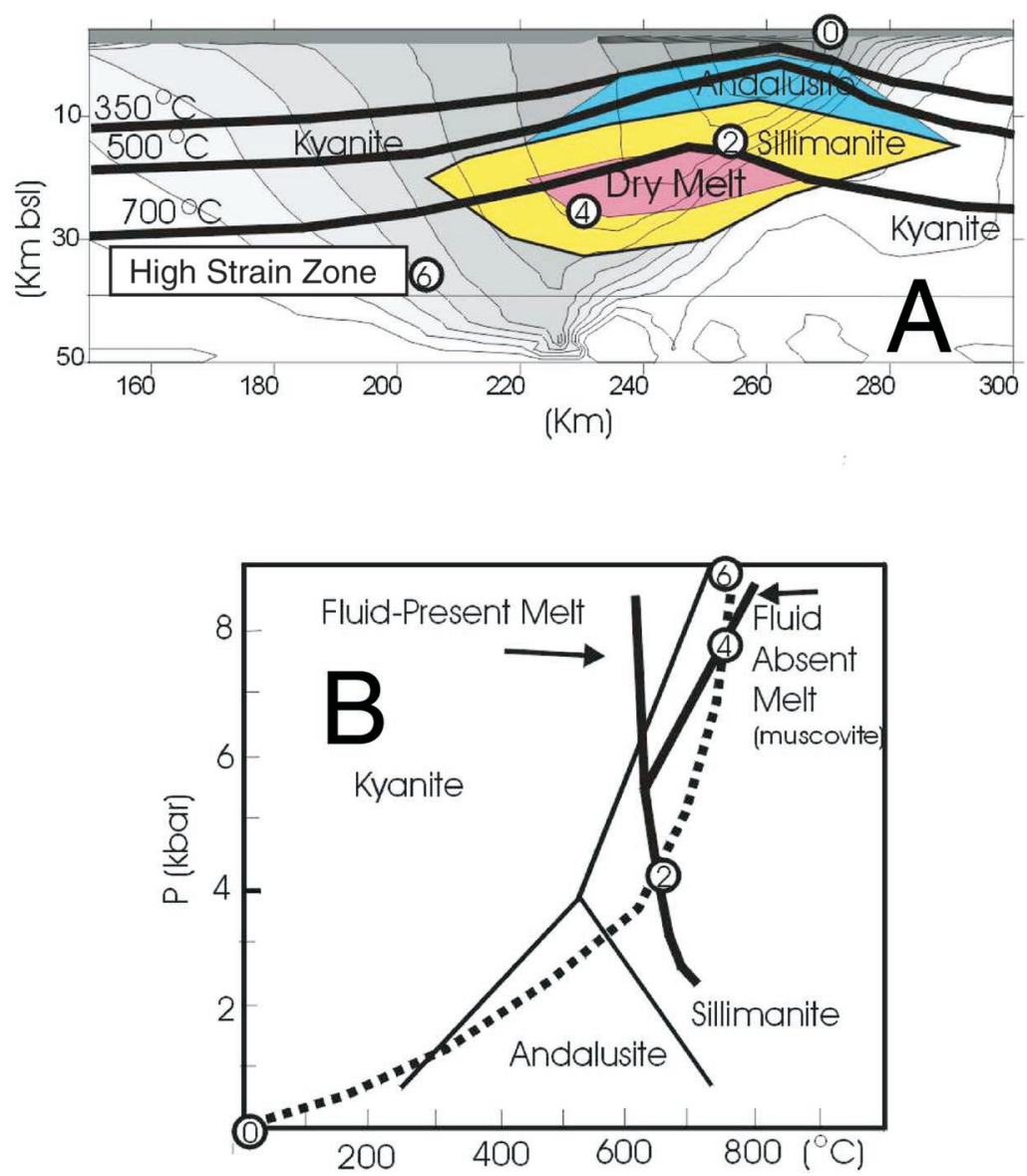

Fig. 7. (A) Geometry of mechanical model for modern Nanga Parbat (Koons and others, unpublished data). The crustal section shows the positions of metamorphic assemblage stability (Koons and others, unpublished data) displayed on a cross-section of vertical velocities (Highest velocity = darkest shade). The numbers within circles represent the time of a particle path of a rock moving from the south of the massif at 6 Ma to the surface at 0 Ma. Also shown is the area of conductive crust located to the south of the massif. (B) Pressure-temperature diagram displaying the model P-T path (dashed line) calculated from the numerical modeling. The numbers correspond to the time (myr) as the rock is exhumed from beneath the massif (see above). Fluid-absent reaction relates to muscovite melting (Patino-Douce and Harris, 1998). The watersaturated melting reaction (l) $\mathrm{qtz}+\mathrm{kfs}+\mathrm{als}+\mathrm{H}_{2} \mathrm{O}$ is from Johannes and Holtz (1996). 


\section{DISCUSSION}

\section{Synthesis of Observations}

The geophysical and geochemical studies discussed above provide a general conceptual framework for fluid flow at Nanga Parbat. These data suggest a fluid flow system that consists of: 1) dry, hot rocks that contain isolated packets of fluid which together rise rapidly from depth; 2) an elevated brittle/ductile transition and isotherms where these metamorphic fluids are released and interact with meteoric fluids; and 3) an upper crust where meteoric fluids are channelized along active fault and shear zones.

A key component of fluid flow at Nanga Parbat is that isotherms and the brittle/ductile transition are strongly elevated beneath Nanga Parbat. Based on numerical modeling, a shallow brittle/ductile transition was originally proposed for Nanga Parbat (Koons, 1987; Craw and others, 1994). This result is now confirmed by the relatively shallow seismic activity and its antiformal shape that indicates the brittle/ductile transition beneath the Nanga Parbat massif is strongly influenced by the ongoing uplift and exhumation. The fluid inclusion data allow us to place constraints on the temperature of the brittle/ductile transition at Nanga Parbat, as defined by seismic activity. The transition from brittle to plastic deformation in the Earth occurs over a range of temperatures depending on lithologic composition, fluid content, pressure, and strain rate (Sibson, 1982; Scholz, 1988; Fournier, 1991; Hill, 1992). For dry quartzofeldspathic rocks, like those at Nanga Parbat, the brittle to ductile transition occurs between $300^{\circ}$ to $450^{\circ} \mathrm{C}$. Evidence from fluid inclusions in veins suggests the transition from brittle to plastic deformation occurs at the upper end of this temperature range at Nanga Parbat. Primary fluid inclusions from veins associated with brittle fractures cutting young structures in the core of the massif include a vapor-rich phase that homogenizes at temperatures up to $415^{\circ} \mathrm{C}$, while fluid inclusions from ductilely deformed veins are inferred to have equilibrated at $450^{\circ} \mathrm{C}$ (Craw and others, 1994 , 1997; Winslow and others, 1994). These fluid inclusion data together with the seismic data suggest that the $\sim 400^{\circ} \mathrm{C}$ isotherm occurs about 5 to 6 kilometers beneath the topographic surface of Nanga Parbat. At these high thermal gradients, rocks pass through the $400^{\circ}$ to $450^{\circ}$ isotherm at shallow depths entering the brittle regime for quartzofeldspathic rocks.

We suggest that the elevated isotherms and brittle/ductile transition is the result of the recent and rapid exhumation of Nanga Parbat rather than intrusion of magmas since both the MT and seismic data show no evidence of a large magma body at depth. In fact, the distribution of low velocities and high attenuation found at Nanga Parbat is consistent with the prediction of numerical models examining the evolution of the conductive geotherm during rapid advection of crustal rocks which indicate that Nanga Parbat should resemble a column of hot rock rising toward the surface (Craw and others, 1994). Thus, the general tectonic framework required to conceptually understand the hydrothermal system is one in which hot rocks from depth are focused into the NPHM region where they are uplifted and rapidly exhumed (Zeitler and others, 2001a, 2001b).

The geophysical and geochemical data suggest that the rocks below the brittle/ ductile transition are relatively dry and contain little interconnected fluid, which is interesting in light of the active debate between the magnetotelluric and petrologic communities about the existence of free water in the lower crust (for example, Yardley and Valley, 1997; Wannamaker, 2000). Results from Nanga Parbat suggest a fluid model consistent with both the MT and geochemical/petrologic data. As stated earlier, the $\mathrm{Sr}$ isotopes of calcite veinlets and high salinity fluid inclusions in metamorphic minerals all suggest that what fluids are present below the brittle/ductile transition are derived from metamorphic reactions. In addition, variations in $\delta^{18} \mathrm{O}$ between the 
gneisses and interbedded calc-silicate rocks indicate little pervasive interaction between the rock and the fluids, leading to the suggestion that the fluids are trapped in discrete packets and are presumably disconnected. This model of stagnant, unconnected metamorphic fluids beneath the brittle/ductile transition is consistent with the high resistivities seen by the MT data.

In contrast, above the elevated brittle/ductile transition the hydrothermal system is dominated by circulation of meteoric water. As mentioned earlier, several pieces of geochemical data show that fluids above the brittle/ductile transition are dominantly meteoric in origin and focused along faults and shear zones; which are: 1) $\delta \mathrm{D}$ and $\delta^{18} \mathrm{O}$ values of gneisses from fault and shear zones are relatively low indicating interaction with meteoric waters at elevated temperatures; 2) hot springs are located along fault zones and the $\delta \mathrm{D}$ and $\delta^{18} \mathrm{O}$ values of these waters give meteoric signatures; and 3 ) the presence of liquid water/boiling, and dry steam fluid inclusions in crosscutting quartz veins indicate infiltration of water-rich fluids along fractures in the brittle regime. All of these geochemical data are consistent with the MT studies, which show that the faults and shear zones are relatively conductive, indicating the occurrence of an interconnected fluid phase.

We suggest that the rapid uplift of Nanga Parbat and resultant elevated topography drove meteoric waters deep into the massif along fractures and fault zones where they interacted with the rising metamorphic rocks and fluids at the brittle/ductile transition. The brittle/ductile transition acted as a physical barrier for this hydrothermal system. Fluids below it were stagnant, unconnected metamorphic fluids that were carried by the rising rocks, and there is no geophysical or geochemical evidence for the migration of meteoric fluids below the brittle/ductile transition. These metamorphic fluids were released during fracturing at the brittle/ductile transition where they interacted with downward percolating meteoric fluids driven by the steep topographic gradients of Nanga Parbat. The fluid system is, therefore, chemically stratified with an increasing meteoric component towards the surface. This stratification is evidenced by the liquid water/boiling fluid inclusions found in the upper-most portions of the system. These fluids exit the massif as boiling hot springs that are found along faults flanking the massif. Small amounts of this meteoric water penetrate downward to the brittle/ductile transition where they form the dry steam fluid inclusions. The deepest fluid inclusions in crosscutting quartz veins (brittle fractures) had the high salinities and $\mathrm{CO}_{2}$ contents which we assume indicates a metamorphic component. This result suggests that there is some mixing between meteoric and metamorphic fluids above the brittle/ductile transition. In this regard it is interesting to note that all of the water-rich or dry steam inclusions occur as primary inclusions within quartz veins that have $\delta^{18} \mathrm{O}$ values $($ mean $=12.0 \pm 1.5$ permil $)$ that are similar to the whole $\delta^{18} \mathrm{O}$ rock values (fig. 2). This result indicates that the fluids that formed the quartz veins were in oxygen isotopic equilibrium with the gneisses, which suggests that the meteoric fluids had isotopically equilibrated with the host rocks in the deeper parts of the hydrothermal system. Isotopic equilibration between quartz veins and wall rocks indicates that above the brittle/ductile transition the rocks experienced relatively low water/rock ratios, except in fault zones.

\section{A Model for the Origin and Evolution of Fluids at Nanga Parbat}

The hydrothermal system discussed can be placed in tectonic context using results from a 3D numerical model for the recent geodynamic evolution of rocks at Nanga Parbat (Koons and others, 2002). In their model, rocks from the south of the massif are focused into the NPHM where they are rapidly uplifted and exhumed. Using particle paths from this 3D model we describe the fluid flow history of a rock packet originally at 35 kilometer depth moving from the south and into the massif where it is exhumed and exposed at Nanga Parbat today (Point 6 to 0 on fig. 7). 
We suggest that the initial fluid flow history related to modern tectonism centered at Nanga Parbat begins well south of the massif. Park and Mackie $(1997,2000)$ show that there is a high conductivity region south of the massif, suggesting the presence of an interconnected fluid to depths of $\sim 20$ kilometers below sealevel. The area of relatively high conductivity is coincident with an area of high strain predicted by the model (fig. 7A adapted from Koons and others, 2002). Although there is no geochemical evidence for these fluids we tentatively suggest that this high-conductivity region may be where metamorphic fluids trapped in the rock from earlier metamorphism connect and are expelled from the deforming region prior to entering the massif. As these dehydrated rocks move into the massif they begin to decompress as the rocks move upward into the area of intense exhumation. At this stage the only water present in the rock occurs in residual muscovite and biotite and no free interconnected water phase exists within the core. This conclusion is consistent with: 1) the MT results for rocks below the brittle/ductile transition; and 2) the observation that the melt reactions initially involve muscovite and later biotite (Whittington and others, 1999) occur in the absence of water and produce volumetrically minor, highly resistive melts and granulites. It is during this stage that we envision the young $(<5 \mathrm{Ma})$ fluid-absent granites are produced (Point 4, fig. 7).

After passing through the core of the massif into temperatures below those of the fluid-absent melting, biotite that has survived transit through the core of the massif is involved in the formation of cordierite and water (Point 2, fig. 7B). The liberated water is in a supercritical state at fluid pressures effectively equal to the mean stress and is carried along with the exhuming rock mass at vertical velocities of $\sim 5 \mathrm{~mm} / \mathrm{yr}$. The strength of this rock and fluid packet increases as the rock enters the steep thermal gradients of the thermal/mechanical boundary layer (fig. 7A).

As the enclosing and cooling rock packet reaches the brittle/ductile transition the frictional strength is exceeded and shear failure occurs as evidenced by the seismic data. Local shear stress and normal stress gradients are steep in this region of extreme topographic relief (Koons and others, 2002) and are reflected in the complex pattern of fault plane solutions (Meltzer and others, 2001). Contemporaneous tensional failure due to thermal contraction is also predicted for this region, and is supported by fluid inclusion and structural observations (Craw and others, 1997).

Brittle failure of the rock packet with minor free fluid instantaneously alters the pressure of the isolated fluid from lithostatic to hydrostatic (assuming that fractures connect to the surface which is plausible for fault zones), thereby causing a jump in state from supercritical to vapor (Point B to B'; fig. 8A, B). We suggest that the vapor-dominated fluid inclusions that require conditions of limited permeability (White and others, 1971) form at this time in the low-permeability base of the brittle/ductile boundary. We also suggest that this zone coincides with the occurrence of microseismicity.

As the rock packet passes through the steep thermal gradients of the brittle/ ductile boundary, permeability increases with thermal shrinking, meteoric water interacts with the exhuming hot rock and the rock enters into the upper Boiling Point Depth (BPD) hydrothermal system (Point G, fig. 8A, B). The change in permeability associated with brittle/ductile transition results in a change from the rock-dominated conductive, lower fluid system to the upper, fluid-dominated hydrothermal system. Coexistence of conductive dominated and convection dominated thermal systems of a similar type is observed in active geothermal systems (Doi and others, 1998) and is predicted from numerical analysis (Germanovich and others, 2001). From this level up, meteoric fluids dominate the system, the crust becomes more conductive and seismic strain release increases rapidly. 

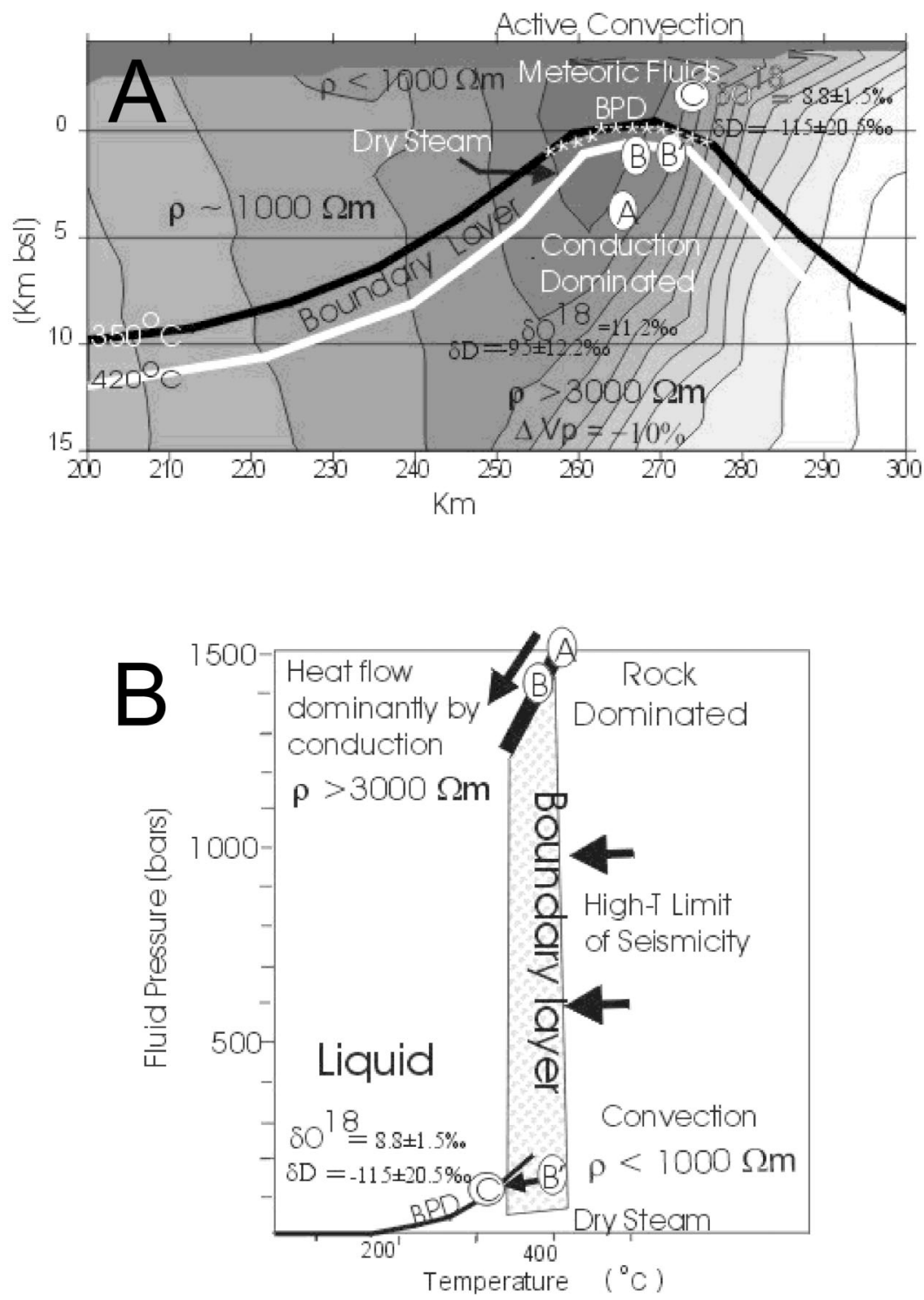

Fig. 8. (A) Detailed distribution of vertical velocity in upper $15 \mathrm{~km}$ of the mechanical model with MT, seismic and isotopic observations superimposed. Deeper limit of the boundary laver is defined from fluid inclusion evidence to correspond with the approximate position of the $420^{\circ} \mathrm{C}$ isotherm calculated from solution of the two-dimensional advection equation (Craw and others, 1994). The upper limit is taken as the $350^{\circ} \mathrm{C}$ isotherm when quartz is predicted to fail by predominantly frictional processes (Brace and Kohlstedt, 1980). The elevated base of seismicity is indicated by the asterisk symbols. Shown also are the approximate resistivities, isotopic, and fluid inclusion data. (B) Expanded low temperature region depicting near surface fluid evolution. Also shown are the MT, seismic and isotopic observations and where they occur at pressure and temperature within the massif. In the Rock-Dominated region (A) fluid approximates mean stress, heat transfer is through conduction, resistivity is high and fluids are not interconnected. With advection and cooling of a rock/fluid packet, brittle failure occurs causing the cooling path (B, B') with coexisting convection and conductive mechanisms (Germanovich and others, 2001). Dry steam fluid inclusions are associated with brittle failure. Further cooling brings the fluid to the BPD curve (Boiling Point Depth) along which vapor and liquid water coexists $(\mathrm{C})$ and meteoric water extensively communicates with the vein assemblage. 


\section{Broader Implications with Regard to Fluid Evolution in Collisional Orogens}

The diverse data sets presented above yield a comprehensive view of the hydrologic, petrologic, electrical and seismic state of the crust within syntaxial regions, or corners of, active collisional mountain belts. We suggest that the hydrothermal system at Nanga Parbat should be characteristic of corners of collisional mountain belts in general, and we predict that a similar system should be present at the eastern Himalayan syntaxis at Namche Barwa. However, the hydrothermal system described here may not be generally applicable to all regions of collisional mountain belts as evidenced by other fluid flow studies.

Our study has many components in common with studies of metamorphic terranes in collisional mountain belts. For example, numerous studies have shown that deep crustal, granulite-grade metamorphic terranes have limited fluid interaction (Valley, 1986) and that the lower portions of the continental crust are essentially dry (Connolly and Thompson, 1989). Studies of many of these systems also show that, like Nanga Parbat, there is a higher-level system dominated by meteoric fluids (Templeton and others, 1998).

That said, however, studies of both ancient and modern collisional mountain belts show that there is abundant evidence for fluids at relatively deep crustal levels. For example, in the Appalachians, where many of the fluid studies have been conducted, there is evidence for substantial fluid flow at depths of $\sim 30$ kilometers in the crust (Ferry, 1994; Ague, 1994). In addition, recent MT studies of the South Island of New Zealand show the presence of fluids at depths up to $\sim 40$ kilometers (Davey and others, 1998; Wanamaker and others, 1998), and these metamorphic fluids are migrating up active faults into the upper crust (Templeton and others, 1998).

We suggest that the limited fluid/rock interaction in the deeper portions of Nanga Parbat reflect the unique and protracted tectonic history of syntaxial corners. The studies demonstrating large-scale fluid flow, mentioned above, occur in terranes where fertile, unmetamorphosed rocks have been or are being tectonically thickened. Because these fertile rocks initially contain relatively large amounts of volatiles as they undergo metamorphism they release the bulk of their volatiles during relatively low-grade metamorphism. Using 1-d heat flow models, Connolly and Thompson (1989) show that: 1) the bulk of the volatiles are lost in the first 30 myr after tectonic thickening, and 2) the time-integrated fluid fluxes increase with increasing structural level as a result of migration of fluid upward in the metamorphic pile. Thus, during initial prograde metamorphism there should be relatively large amounts of fluid present at the higher structural levels. For rocks at 30 kilometer depth (like the Appalachians) time integrated fluxes can be as large as $\sim 2 \cdot 10^{5} \mathrm{~cm}^{3}$ fluid $/ \mathrm{cm}^{2}$ rock, whereas time integrated fluid fluxes deeper in the crust rocks may be an order of magnitude smaller (Connolly and Thompson, 1989).

We suggest that the relatively low amount of fluids in the deeper portions of Nanga Parbat reflects the fact that these relatively deep metamorphic rocks $(\sim 45 \mathrm{~km})$ may have already lost much of their volatile content before they enter the massif. The fluid loss could have occurred during the earliest stages of Himalayan metamorphism or more recently as they are passing through the high strain zone into the massif (see above). Although the earliest portion of the metamorphic history of the massif is poorly constrained mineral inclusions in garnet and garnet zoning patterns show that the rocks were once at relatively high pressure $(\sim 12 \mathrm{kbars})$ metamorphism (Poage and others, 2000). We have no direct ages for this early high pressure metamorphism but have assumed that it reflects early Himalayan metamorphism associated with loading of thrust sheets. There is geochronologic evidence for Himalayan-aged metamorphism in the cover sequence surrounding the massif; giving ages of about $\sim 20$ to $40 \mathrm{Ma}$ (Schneider and others, 1999b; Chamberlain and others, 1989, 1991, respectively). In addition, rocks to the south of the massif record ages of metamorphism $\sim 50 \mathrm{Ma}$ 
(Smith and others, 1994), ages that are associated with the earliest phase of tectonic thickening. Therefore, given the relatively long period of time since the onset of high-grade metamorphism (some 50 myr) and the fact that the rocks at Nanga Parbat were once deeply buried, these rocks would have long since lost most of their volatile content well before the recent exhumation.

In conclusion, we suggest that the general features of the active hydrothermal system at Nanga Parbat should be characteristic of and an integral part of the crustal working that occurs during the later stages of orogenic development. We would expect that the active hydrothermal system described here must have occurred in older mountain belts where late stage orogenic activity rapidly exposed dehydrated continental crust. We also suggest that this type of hydrothermal system may be a key component in surface processes as well. In the two syntaxial regions of the Himalaya the Indus (Nanga Parbat) and Tsangpo (Namche Barwa) Rivers are focused through these regions and these rivers are an integral element for removing crustal mass and facilitating exhumation (Zeitler and others, 2001a, 2001b). It is possible that the hydrothermal systems operative in these syntaxial regions are an important component to riverine geochemistry, both by direct input of hot spring waters and weathering of hydrothermally produced calcite veinlets. For example, ${ }^{87} \mathrm{Sr} /{ }^{86} \mathrm{Sr}$ values of Indus River water increase as the Indus passes through the massif (Karim and Veizer, 2000), which may be due to the chemical weathering of high ${ }^{87} \mathrm{Sr} /{ }^{86} \mathrm{Sr}$ calcite veinlets that have been shown to the dominant control of the high ${ }^{87} \mathrm{Sr} /{ }^{86} \mathrm{Sr}$ flux from the tributaries draining Nanga Parbat (Blum and others, 1998). The role that these hydrothermal systems play in riverine geochemistry should be explored in future studies.

\section{ACKNOWLEDGMENTS}

This research is supported by the Continental Dynamics Program, Earth Sciences Division of the National Science Foundation (EAR-9418154 to Chamberlain; EAR9418849 to Zeitler and Meltzer; and EAR-9418729 to Park). This paper benefited from the reviews of Mike Bickle, Kurt Bucher, and an anonymous reviewer.

\section{REFERENCES}

Ague, J.J., 1994, Mass transfer during Barrovian metamorphism of pelites, south central Connecticut I: Evidence for changes in composition and volume: American Journal of Science, v. 294, p. 989-1057.

Blum, J.D., Gazis, C.A., Jacobson, A.D., and Chamberlain, C.P., 1998, Carbonate versus silicate weathering in the Raikhot watershed within the High Himalayan Crystalline Series: Geology, v. 26, p. 411-414.

Brace, W.F., and Kohlstedt, D.L., 1980, Limits on lithospheric stress imposed by laboratory experiments: Journal of Geophysical Research, v. 85, p. 6248-6252.

Brady, J., 1989, The role of volatiles in the thermal history of metamorphic terranes: Journal of Petrology, v. 29 , p. $1187-1213$.

Burbank, D.W., Leland, J., Fielding, E., Anderson, R.S., Brovic, N., Reid, M.R., and Duncan, C., 1996, Bedrock incision, rock uplift and threshold hillslopes in the northwestern Himalaya: Nature, v. 379, p. 505-510.

Burg, J.P., Davy, P., Nievergelt, P., Oberli, F., Seward, D., Diao, Z., and Meier, M., 1997, Exhumation during crustal folding in the Namche Barwa syntaxis: Terra Nova, v. 9, p. 117-123.

Butler, R.W.H., and Prior, D.J., 1988, Tectonic controls on the uplift of the Nanga Parbat Massif, Pakistan Himalayas: Nature, v. 333, p. 247-250.

Chamberlain, C.P., Jan, M.Q., and Zeitler, P.K., 1989, A petrologic record of the collision between the Kohistan Island-Arc and Indian Plate, northwestern Himalaya, in Malinconico, L. and Lillie, R.J. editors, Tectonics of the Western Himalaya: Geological Society of America Special Papers, v. 232, p. 23-32.

Chamberlain, C.P., Zeitler, P.K., and Erickson, E., 1991, Metamorphism at Babusar Pass, northern Pakistan: implications for the metamorphic evolution of the northwestern Himalaya: Journal of Geology, v. 99, p. $829-849$.

Chamberlain, C.P., Zeitler P.K., Barnet D.E., Winslow, D., Poulson, S.R., Leahy, T., and Hammer, J.E., 1995, Active hydrothermal systems during the recent uplift of Nanga Parbat, Pakistan Himalaya: Journal of Geophysical Research, v. 100, p. 439-453.

Connolly, J.A.D., and Thompson, A.B., 1989, Fluid and enthalpy production during regional metamorphism: Contributions to Mineralogy and Petrology, v. 102, p. 347-366.

Conrad, M.E., and Chamberlain, C.P., 1992, Laser-based in situ measurements of fine-scale variations in the $\delta^{18} \mathrm{O}$ values of hydrothermal quartz: Geology, v. 20, p. 812-816. 
Craw, D., Koons, P.O., Winslow, D., Chamberlain, C.P., and Zeitler, P.K., 1994, Boiling fluids in a region of rapid uplift, Nanga Parbat Massif, Pakistan: Earth and Planetary Science Letters, v. 128, p. 169-182.

Craw, D., Chamberlain, C.P., Zeitler, P.K., and Koons, P.O., 1997, Geochemistry of a dry steam geothermal zone formed during rapid uplift of Nanga Parbat, northern Pakistan: Chemical Geology, v. 142, p. 11-22.

Davey, F.J., Henyey, T., Holbrook, W.S., Okaya, D., Stern, T.A., Melhuish, A., Henrys, S., Anderson, H., Eberhart-Phillips, D., McEvilly, T., Uhrhammer, R., Wu, F., Jiracek, G.R., Wannamaker, P.E., Caldwell, G., and Christensen, N., 1998, Preliminary results from a geophysical study across a modern, continentcontinent collisional plate boundary: the Southern Alps New Zealand, in Klemperer, S.L. and Mooney, W.D., editors, Deep seismic profiling of the continents; II A global survey: Tectonophysics, v. 288, p. 221-235.

Doi, N., Kato, O., Ikeuchi, K., Komatsu, R., Miyazaki, S., Akaku, K., and Uchida, T., 1998, Genesis of the plutonic-hydrothermal system around Quaternary granite in the Kakkonda geothermal system, Japan: Geothermics, v. 27, p. 663-690.

Duan, Z., Moller, N., and Weare, J. H., 1995, Equation of state for $\mathrm{NaCl}_{-} \mathrm{H}_{2} \mathrm{O}-\mathrm{CO}_{2}$ system: Prediction of phase equilibria and volumetric properties: Geochimica et Cosmochimica Acta, v. 59, p. 2869-2882.

Ferry, J.M., 1994, Overview of the petrologic record of fluid flow during regional metamorphism in Northern New England: American Journal of Science, v. 294, p. 905-988.

Fournier, R.O., 1991, The transition from hydrostatic to greater than hydrostatic fluid pressure in presently active continental hydrothermal systems in crystalline rock: Geophysical Research Letters, v. 18, p. 955-958.

Gazis, C.A., Blum, J.D., Chamberlain, C.P., and Poage, M., 1998, An isotopic study of granite genesis: Nanga-Parbat Haramosh Massif, Pakistan Himalaya: American Journal of Science, v. 298, p. 673-698.

Germanovich, L. N., Lowell, R. P., and Astakhov, D. K., 2001, Temperature-dependent permeability and bifurcations in hydrothermal flow: Journal of Geophysical Research, v.106, no. B1, p. 473-495.

Harrison, T.M., Lovera, O., and Grove, M., 1997, New insights into the origin of two contrasting Himalayan granite belts: Geology, v. 25, p. 899-902.

Hill, D.P., 1992, Temperatures at the base of the seismogenic crust beneath Long Valley caldera, California, and the Phlegrean Fields caldera, Italy, in Gasparini, P., Scarpa, R., and Aki, K., editors, Volcanic Seismology, Volume 3: IAVCEI Proceedings in Volcanology, Springer-Verlag, p. 432-461.

Hubbert, M.K., and Rubey, W.W., 1959, Role of fluid pressure in mechanics of overthrust faulting, 1. Mechanics of fluid-filled porous solids and its application to overthrust faulting: Bulletin of the Geological Society of America, v. 70, p. 115-166.

Jenkin, G.R.T., Craw, D., and Fallick, A.E., 1994, Stable isotopic and fluid inclusion evidence for meteoric fluid infiltration into an active mountain belt; Alpine Schist, New Zealand: Journal of Metamorphic Geology, v. 12, p. 429-444.

Johannes, W., and Holtz, F., 1996, Petrogenesis and experimental petrology of granitic rocks: Heidelberg, Springer-Verlag, $312 \mathrm{p}$.

Karim, A., and Veizer, J., 2000, Weathering processes in the Indus River Basin: implications from riverine carbon, sulfur, oxygen and strontium isotopes: Chemical Geology, v. 170, p. 153-177.

Koons, P.O., 1987, Some thermal and mechanical consequences of rapid uplift: an example from the Southern Alps: Earth and Planetary Science Letters, v. 86, p. 307-319.

Koons, P.O., and Craw, D., 1991, Evolution of fluid driving forces and composition within collisional orogens: Geophysical Research Letters, v. 280, p. 935-938.

Koons, P.O., Craw, D., Cox, S., Upton, P., Templeton, A., and Chamberlain, C.P., 1998, Fluid flow during active oblique convergence: a Southern Alps model from mechanical and geochemical observations: Geology, v. 26, p.159-162.

Koons, P.O., Zeitler, P.K., Chamberlain, C.P., Craw, D., and Meltzer, A.S., 2002, Mechanical links between erosion and metamorphism in Nanga Parbat, Pakistan Himalaya: American Journal of Science, v. 302.

Le Fort, P., Cuney, C., Deniel, C., France-Lanord, C., Sheppard, S.M.F., Upreti, B.N., and Vidal, P., 1987, Crustal generation of the Himalayan leucogranites: Tectonophysics, v. 134, p. 39-57.

McCrea, J.M., 1950, On the isotope chemistry of carbonates and a paleotemperature scale: Journal of Chemical Physics, v. 18, p. 849-857.

Meltzer, A., Sarker, G., Beaudoin, B., Seeber, L., and Armbruster, J., 2001, Seismic characterization of an active metamorphic massif, Nanga Parbat, Pakistan Himalaya: Geology, v. 29, p. 651-654.

Misch, P., 1964, Stable association wollastonite-anorthite, and other calc-silicate assemblages in amphibolitefacies crystalline schists of Nanga Parbat, northwestern Himalayas: Beitrage zur Mineralogie und Petrographie, v. 10, p. 315-356.

Nesbitt, B.E., 1993, Electrical resistivities of crustal fluids: Journal of Geophysical Research, v. 98, p. 4301-4310.

Park, S.K., and Mackie, R.L., 1997, Crustal structure at Nanga Parbat, northern Pakistan, from magnetotelluric sounding: Geophysical Research Letters, v. 24, p. 2415-2418.

2000, Resitive (dry?) lower crust in an active orogen, Nanga Parbat, northern Pakistan: Tectonophysics, v. 316, p. 359-380.

Patino-Douce, A.E., and Harris, N.B.W., 1998, Experimental constraints on Himalayan anatexis: Journal of Petrology, v. 39, p. 689-710.

Poage, M.A., Chamberlain, C.P., and Craw, D., 2000, Massif-wide metamorphism and fluid evolution at Nanga Parbat, northern Pakistan: American Journal of Science, v. 300, p. 463-482.

Schneider, D.A., Edwards, M.A., Kidd, W.S.F., Khan, A., Seeber, L., and Zeitler, P.K., 1999a, Tectonics of Nanga Parbat, western Himalaya; synkinematic plutonism with doubly vergent shear zones of a crustal-scale pop-up structure: Geology, v. 27, p. 999-1002.

Schneider, D.A., Edwards, M.A., Kidd, W.S.F., Zeitler, P.K., and Coath, C.D., 1999b, Early Miocene anatexis identified in the western syntaxis, Pakistan Himalaya: Earth and Planetary Science Letters, v. 167, p.121-129. 
Scholz, C.H., 1988, The brittle-plastic transition and the depth of seismic faulting: Geolische Rundschau, v. 77 , p. 319-328.

Searle, M., 1996, Cooling history, erosion, exhumation, and kinematics of the Himalayan-Karakoram-Tibet orogenic belt, in Yin, A., and Harrison, T.M., editors, The Tectonic Evolution of Asia: Rubey Volume, p.110-137.

Sibson, R.H., 1982, Fault zone models, heat flow, and the depth distribution of earthquakes in the continental crust of the United States: Bulletin of the Seismological Society of America, v. 72, p. 151-163.

Smith, H.A., Chamberlain C.P., and Zeitler, P.K., 1992, Documentation of Neogene regional metamorphism in the Himalayas of Pakistan using U-Pb in monazite: Earth and Planetary Science Letters, v. 113, p. $93-105$

1994, Timing and duration of Himalayan metamorphism within the Indian Plate, Northwest Himalaya, Pakistan: Journal of Geology, v. 102, p.493-508.

Tahirkheli, R.A.K., Mattauer, M., Proust, F., and Tapponier, P., 1979, The India-Eurasia suture zone in northern Pakistan: some new data for an interpretation at plate scale, in Farah and Dejong, K.A., editors, Geodynamics of Pakistan: Quetta, Geological Survey of Pakistan, p. 130-135.

Templeton, A.S., Chamberlain, C.P., Koons, P.O., and Craw, D., 1998, Stable isotopic evidence for mixing between metamorphic and surface-derived waters during uplift of the Southern Alps, New Zealand: Earth and Planetary Science Letters, v. 154, p. 73-92.

Upton, P., Koons, P.O., and Chamberlain, C.P., 1995, Penetration of deformation-driven meteoric water into ductile rocks: isotopic and model observations from the Southern Alps, New Zealand: New Zealand Journal of Geology and Geophysics, v. 38, p. 535-543.

Valley, J.W., 1986, Stable isotope geochemistry of metamorphic rocks, in Valley, J.W., Taylor H.P. Jr., and O'Neil, J.R., editors, Stable Isotopes in High Temperature Geological Processes: Mineralogical Society of America Reviews in Mineralogy, v. 16, p. 445-486.

Wannamaker, P.E., 1986, Electrical conductivity of water-undersaturated crustal melting: Journal of Geophysical Research, v. 91, p. 6321-6327.

2000, Comment on "The petrologic case for a dry lower crust" by Yardley and Valley: Journal of Geophysical Research, v. 105, p. 6057-6064.

Wannamaker, P.E., Johnston, J.M., Stodt, J.A., and Booker, J.R., 1997, Anatomy of the southern Cordilleran Hingeline, Utah and Nevada, from deep resistivity profiling: Geophysics, v. 62, p. 1069-1086.

Wannamaker, P.E., Stodt, J.A., Jiracek, G.R., Porter, A.D., Gonzalez, V.M., Caldwell, T.G., and Mcknight, J.D. 1998, Fluid generation and pathways beneath the New Zealand Southern Alps, and geodynamic implications, inferred from magnetotelluric (MT) data: Geological Society of New Zealand Miscellaneous Publication, v. 101A, 241.

White, D.E., Muffler, L.J.P., Truesdell, A.H., 1971, Vapor-dominated hydrothermal systems compared with hot water systems: Economic Geology, v. 66, p. 75-97.

Whittington, A.G., 1996, Exhumation overrated at Nanga Parbat: Tectonophysics, v. 206, p. 215-226.

- ms, 1997, The thermal, metamorphic, and magmatic evolution of a rapidly exhuming terrane: the Nanga Parbat Haramosh Massif, northwestern Pakistan: Ph.D. thesis, The Open University, 432 p.

Whittington, A.G., Harris, N., and Baker, J., 1998, Low-pressure crustal anatexis: the significance of spinel and cordierite from metapeltitic assemblages at Nanga Parbat, northern Pakistan, in Treloar, P.J., and Obrien, P.J., editors, What drives Metamorphism and Metamorphic Relations?: Geological Society of America Special Paper 138, p. 183-198.

Whittington, A.G., Harris, N.B.W., and Butler, R.W.H., 1999, Contrasting anatectic styles at Nanga Parbat, northern Pakistan, in Macfarlane, A., Sorkhabi, R.B., and Quade, J., editors, Himalaya and Tibet: Mountain roots to mountaintops: Geological Society of America Special Paper 328, p. 129-144.

Whittington, A.G., Harris, N.B.W., Ayres, M.W., and Foster, G., 2000, Tracing the origins of the western Himalaya: an isotopic comparison of the Nanga Parbat massif and Zanskar Himalaya, in Khan, M.A., Treloar, P.J., Searle, M.P., and Jan, M.Q., editors, Tectonics of the Nanga Parbat Syntaxis and the Western Himalaya: Geological Society of America Special Publications, v. 170, p. 25-50.

Wickham, S.M., Peters, M.T., Fricke, H.C., and O'Neil, J.R., 1993, Identification of magmatic and meteoric fluid sources and upward-and downward-moving fronts in a metamorphic core complex: Geology, v. 21, p. $81-84$.

Winslow, D.M., Zeitler, P.K., Chamberlain, C.P., and Hollister, L.S., 1994, Direct evidence for a steepened geotherm under conditions of rapid denudation, Pakistan, Himalaya: Geology, v. 22, p. 1075-1078.

Yardley, B.W.D., and Valley, J.W., 1997, The petrologic case for a dry lower crust: Journal of Geophysical Research, v.102, p. 12173-12185.

Zeitler, P.K., 1985, Cooling history of the northwest Himalaya, Pakistan: Tectonics, v. 4, p. 127-151.

Zeitler, P.K., and Chamberlain, C.P., 1991, Petrogenetic and tectonic significance of young leucogranites from the northwestern Himalaya, Pakistan: Tectonics, v. 10, p. 729-741.

Zeitler, P.K., Sutter, J.F., Williams, I.S., Zartman, R.E., and Tahirkheli, R.A.K., 1989, Geochronology and temperature history of the Nanga Parbat Massif, Pakistan, in Malinconico, L.L., and Lillie, R.J. editors, Tectonics of the Western Himalaya: Geological Society America Special Paper, v. 232, p. 1-22.

Zeitler, P.K., Chamberlain, C.P., and Smith, H.A., 1993, Synchronous anatexis, metamorphism, and rapid denudation at Nanga Parbat (Pakistan Himalaya): Geology, v. 21, p. 347-350.

Zeitler, P.K., Koons, P. O., Bishop, M.P., Chamberlain, C.P., Craw, D., Edwards, M.A., Hamidullah, S., Jan, M.Q., Khan, A.A., Khattak, M.U., Kidd, W., Mackie, R.L., Meltzer, A.S., Park, S.K., Pecher, A., Poage, M.A., Sarker, D.A., Schneider, D.A., Seeber, L., and Shroder, J.F., 2001a, Crustal reworking at Nanga Parbat, Pakistan, I. Evidence for erosional focusing of crustal strain: Tectonics, v. 20, p. 712-728.

Zeitler, P.K., Meltzer, A.S., Koons, P.O., Craw, D., Hallet, B., Chamberlain, C.P., Kidd, W.S.F., Park, S.K., Seeber, L., Bishop, M., and Shroder, J., 2001b, Erosion, Himalaya geodynamics, and the geomorphology of metamorphism: GSA Today, v. 11, p. 4-8. 